\title{
Review
}

\section{Dietary Management in Pediatric Patients with Crohn's Disease}

\author{
Luca Scarallo ${ }^{1}$ (1) and Paolo Lionetti ${ }^{1,2, *}$ \\ 1 Gastroenterology and Nutrition Unit, Meyer Children's Hospital, 50139 Florence, Italy; \\ luca.scarallo@gmail.com \\ 2 Department NEUROFARBA, University of Florence, 50139 Florence, Italy \\ * Correspondence: paolo.lionetti@unifi.it
}

check for updates

Citation: Scarallo, L.; Lionetti, P. Dietary Management in Pediatric Patients with Crohn's Disease. Nutrients 2021, 13, 1611. https:// doi.org/10.3390/nu13051611

Academic Editors:

Giuseppe Chiarioni and

Roberto De Giorgio

Received: 31 March 2021

Accepted: 7 May 2021

Published: 11 May 2021

Publisher's Note: MDPI stays neutral with regard to jurisdictional claims in published maps and institutional affiliations.

Copyright: (C) 2021 by the authors. Licensee MDPI, Basel, Switzerland. This article is an open access article distributed under the terms and conditions of the Creative Commons Attribution (CC BY) license (https:// creativecommons.org/licenses/by/ $4.0 /)$.

\begin{abstract}
It has been widely endorsed that a multifactorial etiology, including interaction between genetic and environmental factors, can contribute to Crohn's Disease (CD) pathogenesis. More specifically, diet has proven to be able to shape gut microbiota composition and thus is suspected to play a significant role in inflammatory bowel disease (IBD) pathogenesis. Moreover, poor nutritional status and growth retardation, arising from several factors such as reduced dietary intake or nutrient leakage from the gastrointestinal tract, represent the hallmarks of pediatric CD. For these reasons, multiple research lines have recently focused on the utilization of dietary therapies for the management of $C D$, aiming to target concurrently mucosal inflammation, intestinal dysbiosis and optimization of nutritional status. The forerunner of such interventions is represented by exclusive enteral nutrition (EEN), a robustly supported nutritional therapy; however, it is burdened by monotony and low tolerance in the long term. Novel dietary interventions, such as Crohn's Disease Exclusion Diet or Crohn's Disease treatment with eating, have shown their efficacy in the induction of remission in pediatric patients with CD. The aim of the present narrative review is to provide a synopsis of the available nutritional strategies in the management of pediatric CD and to discuss their application in the dietary management of these patients.
\end{abstract}

Keywords: Crohn's disease; children; nutrition; dietary management

\section{Introduction}

Crohn's Disease (CD) is a chronic idiopathic inflammatory affection involving the gastrointestinal (GI) tract. CD is a lifelong, currently incurable condition, whose natural history is characterized by alternating quiescent periods and active flares of inflammation, progressing to bowel damage and subsequent considerable morbidity [1,2]. To date, approximately $10 \%$ of CD cases are diagnosed before the patient's 17 th birthday, with a progressive acceleration in incidence in the last few decades [3,4]. When arising during childhood or adolescence, CD typically presents with a more extensive/panenteric phenotype [5,6]. In addition, as the disease occurs in a period of important developmental milestones, such as growth and puberty, children and adolescents are in a particularly vulnerable situation and management strategies need to deal with these peculiarities $[7,8]$. The exact pathophysiology of CD remains undetermined. It has been widely endorsed that multifactorial etiology, including an interaction between genetic and environmental factors, can contribute to CD pathogenesis [9]. Advances in DNA sequencing have led to the identification of more than 200 risk loci [10], which are estimated to explain only $25 \%$ of the inheritability of inflammatory bowel disease (IBD) [11,12]. The recent progress in basic and clinical science has changed our appraisal of the role of non-genetic factors in IBD susceptibility [13]. The dramatic rise in the incidence of IBD in newly industrialized countries shifting to Western dietary habits [14] represents one of the foremost clues to the relevant influence of environmental factors, including diet, on IBD pathogenesis. Dietary components have proven to be able to shape gut microbiota composition $[15,16]$ and intestinal wall permeability [17], altering the interaction between host and intestinal 
microbiota, the latter being addressed as a master regulator of metabolism and immune response $[13,18,19]$. More specifically, high animal or dairy fat, animal protein, wheat, emulsifiers and thickeners appear to be strongly associated with intestinal inflammation in animal models [13]. Historically, growth failure at disease presentation represents one of the hallmarks of pediatric IBD, especially in $\mathrm{CD}$, where it has also been associated with underweight and malnutrition [20]. Growth failure and malnutrition in IBD develop from a combination among low caloric input owing to decreased food intake (because of abdominal pain or restricted diets), malabsorption, increased basal metabolism and chronic inflammatory condition [21]. Undernutrition and nutritional deficiencies are associated with poorer clinical outcomes, such as higher infection rates or in-hospital length of stay, and with higher postoperative complications [22]. Despite being acknowledged as a multifactorial disease, where genetics, the immune system and the environment interplay, leading to disease onset and maintenance, treatment of $C D$ remains focused on immune suppression (such as corticosteroids, methotrexates, thiopurines and biologic agents such anti-tumor necrosis factor alpha (TNF $\alpha)$ ) [23]. Furthermore, notwithstanding the expansion of medical treatments, $\mathrm{CD}$ is still associated with non-negligible morbidity, mainly owing to its progression to complicated disease [24]. Moreover, the use of immunosuppressant agents and biologic drugs bears with it an increased risk of serious infections and malignancies $[25,26]$. In turn, corticosteroid use in pediatric patients affected by $C D$ is associated with growth impairment and bone maturation delay [27,28]. Lastly, the achievement of consistent rates of deep outcomes (such as mucosal healing), along with sustained maintenance of remission, are still unfulfilled objectives $[29,30]$. Multiple studies in children with $C D$ have demonstrated the efficacy in the induction of remission, the excellent safety profile and the nutritional benefits of exclusive enteral nutrition (EEN) [31,32]. However, EEN has tolerability issues, limiting compliance and widespread clinical application [33]. From this perspective, multiple research lines have investigated the efficacy of novel dietary therapeutic strategies designed to allow access to food excluding potential harmful substances for intestinal wall integrity and microbiome [34,35]. Such dietary strategies may enable the simultaneous targeting of the induction and maintenance of remission, allowing medication sparing, with the modulation of the gut microenvironment and the correction of possible macro- or micronutrient deficiencies and optimization of nutritional status. With this narrative review, we aimed to provide a synopsis of nutritional assessment of children with $C D$, the available nutritional strategies and their application in the dietary management of these patients.

\section{Materials and Methods}

Aiming to gather a comprehensive overview of existing dietary strategies for the management of pediatric CD, we performed an extensive literature search in Medline (PubMed, inception to January 2021), using "Crohn's disease", "children", "pediatric", "diet", "micronutrients", "macronutrients", "deficiency", "nutrition", "nutritional", "management", "mechanism" and "malnutrition" as keywords. Studies not in English were not included. There were no other specific inclusion or exclusion criteria for this narrative review.

\section{Mechanisms and Clinical Implications of Undernutrition in Children with CD}

The inflammatory involvement in CD may extend throughout the length of the small bowel, thus impairing the absorption and processing of nutrients [36]. However, several other factors contribute to development of inadequate nutritional states in IBD [37]. One of the foremost determinants of malnutrition in IBD is reduced oral intake of food. Active disease often leads to reduced appetite due to abdominal symptom onset (abdominal pain, diarrhea, vomiting and nausea) [38]. Moreover, inflammation itself (i.e., via TNF- $\alpha$ and IL-6) can cause a reduction in appetite via catabolic effects and hypothalamic weight regulation [39]. In addition, some of the most commonly prescribed medications can induce nausea, vomiting and/or anorexia [40]. Lastly, some patients and/or their parents believe that certain foods may worsen, or even elicit, their symptoms. Therefore, they are inclined 
to modify their diet, excluding putative noxious triggers, in order to control their disease. According to a recent European survey, the most commonly charged foods are grains (29\%), milk $(28 \%)$, vegetables $(18 \%)$ and fruits $(11 \%)$ [41]. This behavior may have detrimental effects on nutritional status [42]. The intestinal epithelium can be easily disrupted during gut inflammation [43]. Impaired epithelial transport and loss of mucosal integrity are tightly associated with malabsorption. Indeed, deterioration of epithelial function leads to alterations of ionic transport, which consequently cause loss of fluids and electrolytes [38]. Furthermore, inflammation of the intestinal mucosa results in chronic leakage of blood and proteins [38]. Surgery is also associated with impairment of macro- and micronutrient absorption [38]. Bowel resections can cause accelerated intestinal transit and diarrhea, thus reducing the contact time of the luminal contents with the mucosal surface. Lastly, conflicting evidence exists regarding Resting Energy Expenditure (REE). REE represents the energy needs for an individual in resting condition [44]. Increased REE is thought to contribute to augmented caloric requirements in patients with active IBD. However, the latter issue remains controversial, as some studies have documented a positive correlation between REE and disease activity [45], whereas some others have not [46] (Figure 1).

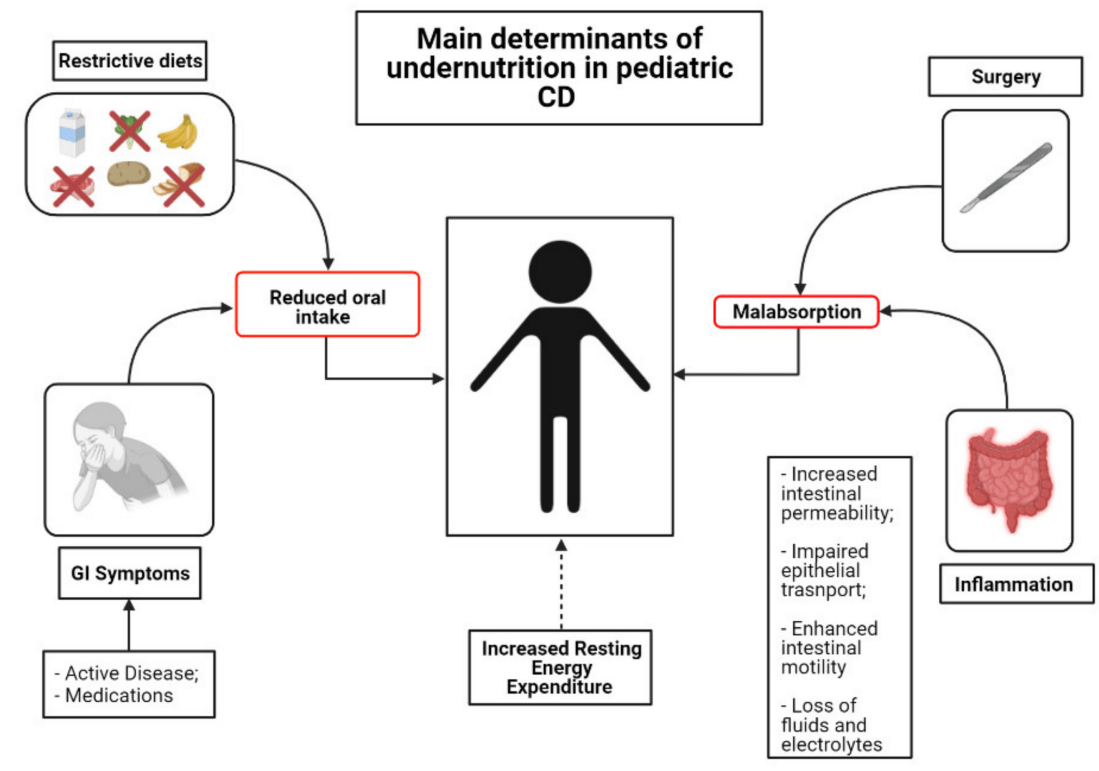

Figure 1. Mechanisms of undernutrition in children with CD.

Linear growth impairment may be the first presenting symptom in up to $46 \%$ of children and adolescents affected by CD [47,48]. The prevalence of undernutrition and growth impairment has substantially decreased throughout the last few decades among patients with IBD $[47,49,50]$. However, irrespective of treatment modality, impaired linear growth and underweight still affect a significant proportion of pediatric patients with CD [51]. Underweight at diagnosis is associated with poorer disease outcomes [21,52]. In a retrospective longitudinal study, Yerushalmy-Feler reported that BMI in the lower quartile at diagnosis was associated with disease flares (HR: $3.212, p=0.016$ ) and with the need for anti-TNF- $\alpha$ (HR: 4.489, $p=0.021$ ) in a cohort of children with IBD [52]. In a subsequent study from the same group, BMI in the lower quartile at 6,12 and 18 months from diagnosis was associated with disease exacerbations (HR: 1.90, 1.98 and 2.43, respectively, $p<0.021$ ) [21]. Children affected by CD have an altered body composition compared to healthy controls [53,54]. Thangarajah et al. [53] performed a systematic review aiming to define the alterations in non-bone tissue compartments in children with IBD. The results of the review showed that children affected by CD have a lower lean mass compared to healthy subjects [53]. In a recent prospective study, Ward et al. [55] enrolled 73 children with newly diagnosed CD to assess the impact of IBD on musculoskeletal health. The authors reported that total body lean mass $(z$-score -2.5 , SD 1.1, $p<0.01$ ) 
was low for age and gender. Furthermore, jumping mechanography demonstrated low muscle power [55]. Interestingly, children and adolescents with IBD show chronic deficits in lean body mass in spite of weight restoration and quiescent disease [56,57]. Persistence of lean mass deficiency negatively affects metabolic homeostasis, physical activity and bone mass accrual along with bone architecture and it is known to increase the risk of infections [58,59]. Moreover, lean mass deficit is known to affect negatively also some of the specific disease-related outcomes in IBD. In a retrospective study including 68 patients affected by IBD, Holt et al. [60] reported that lower values of skeletal muscle areas at TNF- $\alpha$ initiation were associated with a shorter time to loss of response. Despite advances in medical therapies, non-negligible numbers of patients during their disease course require a surgical intervention [61]. Unfortunately, undernutrition is a frequent clinical feature of children and adolescents who are referred to surgery. A long disease course, along with persistently active mucosal inflammation and the side effects of the multiple lines of medications, contribute to malnourishment in such patients. Undernutrition can have detrimental effects on post-surgical course. In a retrospective study on 161 CD patients who underwent elective ileocecal resection, poor nutritional status was independently associated with increased risk of postoperative septic complications [62]. Recently, the clinical implications of diminished lean body mass have been investigated by Ryan et al. [63]. Despite the vast heterogeneity in the assessment of sarcopenia, in a systematic review, the authors demonstrated that lean body mass deficit can predict the need for surgical intervention in patients with IBD and it is further associated with higher rates of major postoperative complications [63].

\section{Nutritional Assessment and Supplementation}

The identification of patients at risk of undernutrition is the first fundamental step aimed to detect those patients in whom nutritional and dietary interventions may bring major benefits. Nutritional assessment is a global outcome that encompasses multiple facets such as anthropometry measurements, clinical examination and assessment of dietary intake along with appraisal of socioeconomic environment. According to a recent position paper published by the European Society of Gastroenterology Hepatology and Nutrition (ESPGHAN) [44], weight, height and BMI z-scores should be used for assessment of the nutritional status at each visit in children affected by IBD. Evaluation of linear growth is of the utmost importance in children with $C D$, as it reflects both disease course and treatment success, and should be performed through height Standard Deviation Score (SDS) and height velocity SDS for a period of 6 to 12 months [44]. Moreover, as CD can be associated with delayed puberty, pubertal development should be closely monitored [44]. Pubertal stage should be assessed regularly from diagnosis in children aged 10 years and older, and at least annually during follow-up visits until puberty is completed [44]. Beyond the appraisal of nutritional status and pubertal development, it is likewise paramount to assess dietary intake as part of the follow-up for pediatric patients with CD. Patients and / or their caregivers may tend to self-restrict their diets [64]. Inadequate food intake, with lower consumption of energy, fiber, carbohydrates and several micronutrients, has been consistently described both in active disease and in remission in children affected by CD [65]. According to the last ESPGHAN position paper on Nutrition in Pediatric IBD, a 3 to 5-day dietary record is recommended as the best-suited method to perform the quantitative evaluation of energy and nutrient intake [44] and it should be performed at least annually in older children and at least twice per year in younger IBD patients [44].

\subsection{Macronutrients}

Macronutrients include proteins, carbohydrates and lipids. Children and adolescents affected by CD seem to have similar nutritional requirements to their healthy peers [44]. However, data arising from the few studies who investigated protein requirements in children and adolescents with $\mathrm{CD}$ suggest that, in phases of active disease, protein demand may be increased $[66,67]$. Protein breakdown has been demonstrated to be reduced after 
surgical intestinal resection in children with active CD [45]. Further, one small study including 15 pediatric $C D$ patients undergoing metabolic assessment immediately before and after the first infliximab infusion reported that TNF- $\alpha$ therapy reduced proteolysis and improved the protein balance in parenterally fed patients [68]. These findings suggest that protein intake may be increased by $25 \%$ during the active phases of disease in order to mitigate protein loss [44]. To date, no studies have demonstrated a different requirement of carbohydrates and fats in children affected by $C D$.

\subsection{Micronutrients}

\subsubsection{Iron}

Iron deficiency (ID) and Iron Deficiency Anemia (IDA) are frequently encountered clinical entities in pediatric IBD [69,70]. Using the World Health Organization definition of anemia, its prevalence at diagnosis reaches $78 \%$ in pediatric IBD populations [71-73]. Moreover, anemia affects up to $42 \%$ of children with IBD one year after diagnosis $[69,74]$ and it has been reported to be more frequent in pediatric populations than in adult ones both at diagnosis and at follow-up [74]. Anemia of pediatric IBD has a complex and multifactorial pathogenesis, but the most common etiology arises from a combination of IDA and anemia of chronic diseases (ACD) [70]. More specifically, IDA has been reported as the leading cause of anemia in children with IBD and with $C D[75,76]$. Some reports have shown that, despite achievement of clinical remission, a non-negligible rate of children with IBD are affected by anemia at one-year follow-up [77]. These findings suggest that anemia is a relevant comorbidity for children with $\mathrm{CD}$ and that it may not resolve unless specific therapeutic interventions. When dealing with a child affected by IBD and anemia, the first therapeutic approach should include providing a balanced and diversified diet with iron-rich foods along with enhancement of alimentary iron absorption (i.e., pairing non-heme iron sources with food rich in ascorbic acid or avoiding coupling with foods that may impair iron absorption). Once having provided adequate control of disease activity and optimized dietary iron intake, the next step in case of persistence of IDA is represented by iron supplementation [70]. The choice of whether to administer oral or parenteral iron supplementation is not always straightforward [70]. Oral supplementation formulations have the relative advantage of not requiring infusions and thus scheduled access to the hospital, of being easily available and less expensive compared to parenteral products. However, concerns exist regarding their well-documented gastrointestinal side effects [78] and the possibility of adding a symptom burden in addition to those of IBD. Indeed, the intolerance rate is a frequent finding, leading to discontinuation in up to $50 \%$ of patients [79]. Moreover, some authors have suggested that oral supplementation with iron formulations may negatively impact intestinal inflammation [80,81]. More recently, a novel oral iron formulation, ferric maltol, consisting of a single ferric ion $\left(\mathrm{Fe}^{3+}\right)$ chelated with high affinity to three maltol molecules, has been demonstrated to be safe, effective and well-tolerated in patients with IDA and IBD who had reported poor tolerance to other oral ferrous preparations [82]. Oral formulations have also been associated with alterations of gut microbiota [83]. However, in a recent prospective, controlled, open-label trial, Rampton et al. [84] demonstrated that oral iron supplementation did not increase disease activity in adolescents and adults with IBD over a period of 6 weeks. Therefore, oral iron supplementation may be used in children and adolescents with milder grades of anemia and inactive disease [70]. Besides oral iron compounds, different intravenous formulations are available as therapeutic options for IDA in patients with IBD. Whereas, historically, high-molecular-weight intravenous iron compounds were burdened by a significant rate of side effects and therefore underused due to safety concerns, the introduction of low-molecular-weight formulations led to a significant decrease in adverse effects [85]. Various studies performed in children and adolescents with IBD reported a high efficacy of intravenous iron formulations with a relatively low rate of adverse events [86-89]. Mamula et al. [86] reported their retrospective experience with intravenous iron dextran infusions in 70 children affected by IBD. The authors observed a significant 
rise in $\mathrm{Hgb}$ levels, with an average increase of $2.9 \mathrm{~g} / \mathrm{dL}$. Hypersensitivity reactions were rare: only $9 \%$ of patients experienced infusion reactions, none of which was severe [86]. Further, Powers et al. [90] reported their retrospective experience of the administration of intravenous ferric carboxymaltose in children affected by IBD who responded poorly to oral iron formulations. Among the 72 patients included in the study, a median $\mathrm{Hgb}$ rise of $3.2 \mathrm{~g} / \mathrm{dL}$ was reported, with only seven children (16\%) reporting minor adverse infusion reactions [90]. Intravenous iron preparations are effective and well tolerated. Their administration should be envisaged in children with CD with moderate-to-severe forms of anemia and in those patients who are intolerant or unresponsive to oral iron compounds [70].

\subsubsection{Vitamin B12 and Folate}

Vitamin B12 status can be assessed by measuring either serum B12 levels or, more accurately, by methylmalonic acid and homocysteine levels [91]. Ileal disease or resection may mediate vitamin B12 malabsorption, placing CD patients at risk of deficiency [92]. Other postulated mechanisms for vitamin B12 deficiency include small bowel bacterial overgrowth, reduced intake, increased physiologic requirements and protein losing enteropathy [92]. A systematic review including 3732 patients from 42 studies concluded that $C D$ without ileal resection (or with a resection of less than $20 \mathrm{~cm}$ ) did not increase the risk of B12 deficiency [92]. A recent systematic review analyzed eight studies that investigated vitamin B12 status in children with IBD. The authors observed an overall low rate of B12 deficiency in the population studied [93]. One study reported that ileal or ileocolonic resection increased the risk of abnormal serum vitamin B12 concentrations [94]. According to the latest ESPGHAN workgroup recommendations [44], vitamin B12 screening should be performed in all patients with a history of ileal or ileocolonic resection and in those patients with suspected vitamin B12 malabsorption. When depleted, patients should be treated with intra-muscular injections [44].

Folate (vitamin B9) levels can be measured in serum or, more accurately, in red blood cells (RBC) and also, indirectly, by measuring serum homocysteine levels [44]. Studies conducted in adult $\mathrm{CD}$ patients have reported a rate of folate deficiency ranging from $20 \%$ to $30 \%$ [94-96]. Pediatric data are limited. However, folate deficiency appears to be infrequent in children affected by CD [93]. According to ESPGHAN's recommendations, children should receive additional folic acid supplementation ( $1 \mathrm{mg}$ daily or $5 \mathrm{mg}$ weekly) when being treated with methotrexate (MTX), as it acts by inhibiting folate's cellular uptake [44].

\subsubsection{Calcium and Vitamin D}

Restriction of milk and dairy products consumption is a common issue in patients affected by IBD and CD $[97,98]$. Moreover, chronic inflammation, corticosteroid use, suboptimal nutritional status, delayed puberty and a sedentary lifestyle all contribute to the genesis of a low bone mineral density (BMD) in children with IBD [99-101]. Bone mass accrual occurs predominantly during the phase of transition from childhood to adolescence. Any disruption of such a complex and delicate phenomenon may have detrimental longterm consequences. Sigurdsson et al. [102] performed a prospective longitudinal study including 74 children affected by IBD followed into young adulthood. They reported that male patients with childhood-onset IBD had a BMD lower than reference values [102]. Anat Guz-Mark et al. [103] also reported similar results. Among the 61 young adult patients with pediatric-onset IBD, the authors reported a median BMD $z$-score significantly lower than those of the healthy population $(p<0.001)$, with a high prevalence of both osteopenia (defined as BMD $z$-score $\leq-1 \mathrm{SD}, 44.3 \%$ ) and osteoporosis (defined as BMD $z$-score $\leq-2.5 \mathrm{SD}, 8.2 \%$ ). Vitamin $\mathrm{D}$ deficiency has been consistently reported across several pediatric CD populations [104,105]. The latest guidelines recommend weightbased supplementation of vitamin $\mathrm{D}$ when deficiency is present $(25(\mathrm{OH}) \mathrm{D}$ concentrations below $50 \mathrm{nmol} / \mathrm{L}$ or $20 \mathrm{ng} / \mathrm{mL}$ ) [44]. Several strategies for vitamin D repletion exist. 
Various regimens are used, ranging from 4000 IU daily to 50,000 IU weekly [106]. Recently, Lee et al. [107] have also demonstrated, in a prospective randomized study, the efficacy of a single high dose of vitamin D of 300,000 IU. When compared to administration of a weekly dose of 50,000 UI, the authors observed an equivalent rise in vitamin D in the two groups $(53.6 \pm 17.3 \mathrm{ng} / \mathrm{mL}$ vs. $54.6 \pm 17.5 \mathrm{ng} / \mathrm{mL}$ ) [106], significantly far from toxicity levels [107]. Despite its pivotal role in the regulation of mineral and bone homeostasis, vitamin D plays a key part in the modulation of both the innate and adaptive immune response [108]. Low serum vitamin $\mathrm{D}$ levels have been demonstrated to be associated with disease activity and with poorer clinical course in adult patients with IBD [109]. Recently, El Amrousy et al. [110] conducted a double-blinded, randomized clinical trial on 120 children and adolescents affected by IBD and hypovitaminosis D who were randomized to receive either oral vitamin D3 in a dose of $2000 \mathrm{IU} /$ day or placebo for 6 months. The authors reported that vitamin D supplementation was significantly inversely associated with clinical activity scores (PCDAI: $13.6 \pm 3.1$ in treatment group vs. $27.5 \pm 3.5$ in placebo group; PUCAI: $11.1 \pm 2.4$ in treatment group vs. $21.8 \pm 2.9$ in placebo group; $p=0.001$ ) and with serum and fecal inflammatory markers (C-reactive protein (CRP), fecal calprotectin (FC) and pro-inflammatory cytokines). A recent systematic review with meta-analysis of adult studies, including 970 patients with IBD from 12 randomized controlled trial (RCT) and 4 observational studies, demonstrated that supplementation of vitamin D significantly increased serum levels of $25(\mathrm{OH})$ vitamin D in both UC and CD patients. Lastly, the analysis revealed a reduction in clinical activity indices (Harvey-Bradshaw Index) and of inflammatory markers (high-sensitivity CRP) after supplementation with vitamin D [111].

\subsection{Dietary Fiber}

Dietary fiber describes a complex group of non-digestible components of cell walls [112]. Fibers can withstand the gastric acidity and are not metabolized by human gut cells. In the large bowel, dietary fiber serves as substrates for fermentation by the gut microbiota. Such a process produces byproducts, such as short-chain fatty acids (SCFAs) [113]. The main SCFAs (acetate, butyrate and propionate) have been demonstrated to positively affect the host in several ways, including offering energy supply to colonic epithelial cells and reducing the extent of inflammation in IBD [114]. Dietary fiber restriction has been associated with a higher consumption of colonic mucus by bacterial species, potentially contributing to inflammation [17]. Dietary fiber intake of children with IBD has been demonstrated to be suboptimal when compared to healthy controls [115] or recommended intake guidelines, regardless of whether the patient had active or inactive disease [116]. According to the recent recommendations from the Nutrition Cluster of the International Organization for the Study of Inflammatory Bowel Diseases, there is currently no evidence to support the restriction of dietary fiber in patients without intestinal strictures or obstructions [117].

\section{Nutritional Therapies}

Nutritional status represents one of the foremost determinants of both clinical and surgical outcomes for patients affected by CD [118]. From this perspective, the identification, prevention and correction of nutritional deficiencies can be considered a therapeutic intervention as crucial as the choice of adequate pharmacological strategies. Indeed, malnutrition and impaired linear growth can be suggestive of active disease and their restoration should be considered as a treatment goal [44].

\subsection{EEN}

EEN is a nutritional treatment strategy that provides the total amount of calories and nutrient requirements of patients through a proprietary liquid formula administered orally via an enteral tube. There are three main types of EEN currently available, namely elemental (amino-acid-based), semi-elemental (oligopeptide-based) and polymeric (wholeprotein-based) formulas [119]. Elemental formulas are entirely antigen-free, and they are best-suited in cases of severe malabsorption, where there may be impairment of the 
gastrointestinal tract. Oligopeptide formulas are peptide-based feeds where the source of nitrogen is represented by peptides of four or five amino acids in length obtained from hydrolysis of whole proteins. Lastly, polymeric feeds contain whole proteins from milk, egg, soy or even meat [119]. Efficacy of EEN does not vary according to the type of feed, as it also has been recently confirmed by a Cochrane review of EEN for the induction of remission in $\mathrm{CD}$ that evaluated the different formulas composition and found no difference in efficacy or in side effects [120]. However, polymeric feeds are more palatable when consumed orally and they are more commonly used to improve adherence to treatment, helping to overcome one of the major limitations of EEN treatment [121]. EEN has no major medical side effects. The more commonly reported adverse effects by patients on EEN include diarrhea, nausea and vomiting. Moreover, in pediatric CD, in extremely selected cases with prolonged nutritional restriction, abrupt re-introduction of calories may be associated with refeeding syndrome [122,123].

\subsubsection{Mechanism of Action}

Impaired epithelial barrier function, alterations of normal gut microbiota composition and translocation of bacteria through the intestinal epithelium have all been described in IBD and thus in CD [13,124-126]. Despite the wide availability of data regarding EEN utilization for the induction of remission in $\mathrm{CD}$, there is a considerable knowledge gap in our understanding of its exact mechanism of action. EEN has the ability to mitigate the aberrant immune response that characterizes $\mathrm{CD}$ and thus to relieve inflammation. This has been highlighted by several in vivo and in vitro studies [127-129]. EEN is thought to exert its anti-inflammatory properties through deactivation of the major intracellular signaling pathways NF-KB $[129,130]$. Two amino acids contained in the polymeric formula, arginine and lysine, have been addressed as responsible for this effect via interference with its kinase activity [131]. In an in vitro study, the polymeric formula has also been demonstrated to reduce the production of pro-inflammatory cytokines as IL-6, IL-8, IL$1 \mathrm{~b}$ and IFN- $\gamma$ by peripheral blood mononuclear cells isolated from children with active CD [132]. Besides the reduction of pro-inflammatory cytokines, EEN has also been shown to be able to enhance TGF- $\beta 1$ [133], an immune-suppressive cytokine whose signaling pathway has been detected in patients with active CD's intestine [134]. Consequently, some authors have postulated that enrichment of EEN formulations with TGF- $\beta$ might boost their anti-inflammatory properties [135]. Further, EEN has been demonstrated to increase the expression of some of the adhesion molecules involved in the innate intestinal immune response. Repletion of such transmembrane proteins may prevent bacterial interaction with intestinal epithelial cells and thus their activation of dendritic cells, macrophages and the mucosal inflammation cascade $[136,137]$. EEN has also been shown to improve mucus integrity and gut permeability in children affected by CD. This effect is thought to be exerted by: (i) avoidance of dietary products that impair intestinal barrier [13]; (ii) reduction of pro-inflammatory cytokines that have been implicated in the reduction of permeability [138]; (iii) restoration of cell-to-cell adhesion molecules (such as occludin and claudin-1) [138] (Figure 2).

Pediatric patients with newly diagnosed CD display reduced microbial diversity when compared to healthy controls [139], with a relatively lower representation of Firmicutes as well as an expansion of Proteobacteria [140]. Moreover, the intestinal metabolic signature of patients with CD, including short-chain fatty acid (SCFA) reduction [141,142], amino acid abundance [142] and bile acid composition dysregulation [143], pronouncedly differs from those of healthy controls. Modulation of gut microbiota along with intestinal metabolic changes are among the likely mechanisms through which EEN exerts its functions $[144,145]$. Interestingly, some studies have demonstrated that EEN administration is associated with a reduction in the alpha-diversity of gut microflora, a parameter usually associated with microbiota "fitness" [146]. Additionally, a reduction in SCFAs such as butyrate, a presumed beneficial metabolite for the host, has been observed during successful EEN induction treatment [146]. However, it is worth noting that these findings are not so surprising when 
looking at the composition of EEN. More specifically, shortage of complex fermentable carbohydrates reduces SCFA substrates, whereas the limited number of EEN components, compared to a regular diet, may account for the reduction in microflora diversity [144]. Indeed, although fiber has been considered to exert a potential clinical benefit for patients with CD, the vast majority of EEN formulations do not contain any fiber [147]. Moreover, among the few EEN formulations containing fiber, the main ones were slightly different from the range of fibers included in standard diets. The latter observation, however, does not suggest that fiber is harmful, but rather that its removal from the diet does not worsen symptoms in patients with CD [147].
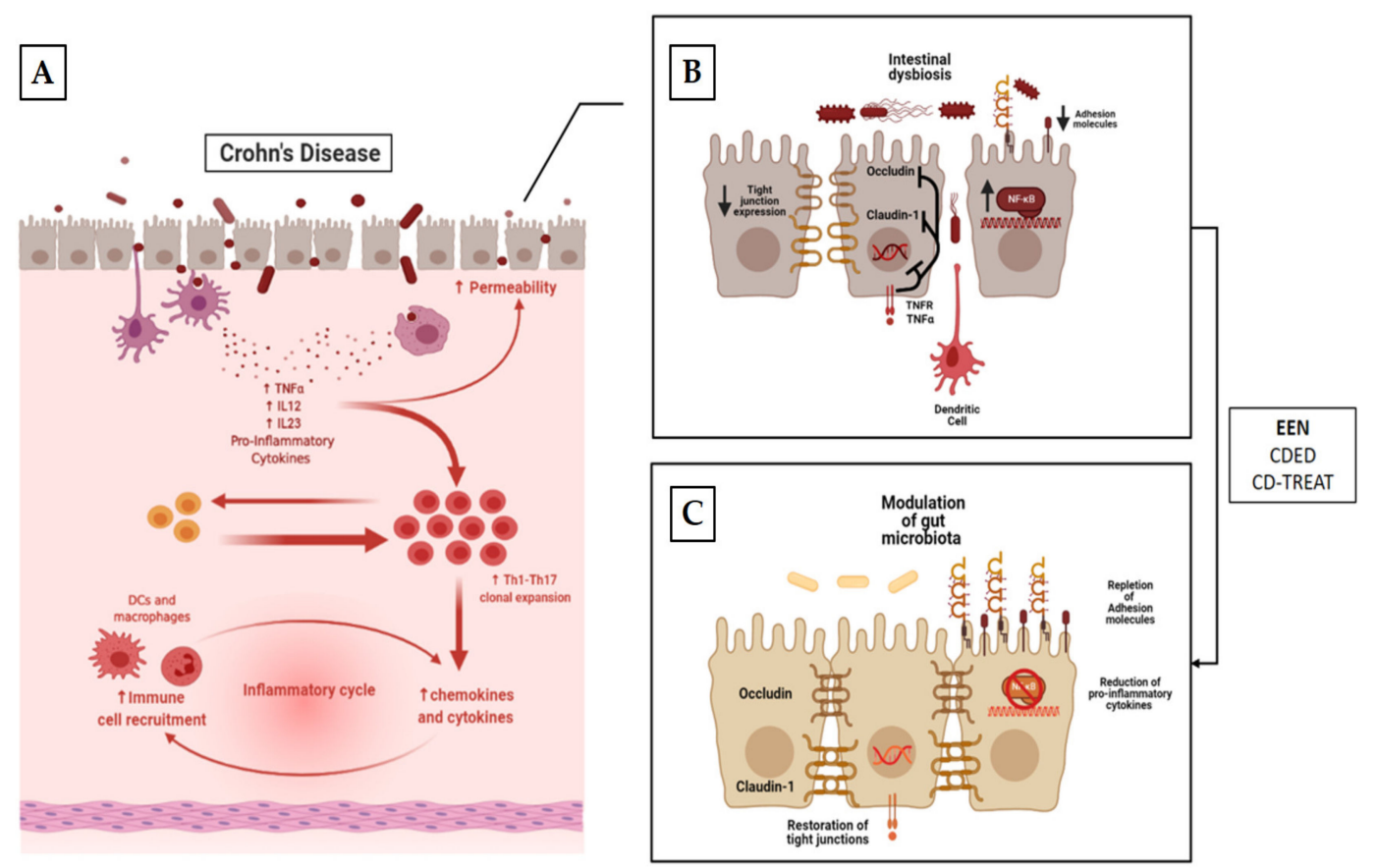

Figure 2. Mechanism of action of EEN, CDED and CD-TREAT. The panels (A,B) depict the potential pathogenic effects of diet on the development of CD. (i) Reduction in the expression of apical membrane adhesion molecules, which cause increased interactions between bacteria and epithelial membrane. (ii) Reduction in the synthesis and expression of lateral tight junction proteins, causing defects in gut barrier. As a consequence, there is an amplification of the interaction between gut bacteria and immune cells, causing stimulation of pro-inflammatory cytokine secretion and attracting and stimulating the proliferation of pro-inflammatory T-cells with the establishment of a pro-inflammatory milieu along with a self-empowered mechanism. Panel (C) describes the potential effects of nutritional interventions. (i) Modulation of gut microbiota. (ii) Enhancement of expression of apical adhesion molecules. (iii) Increased expression of tight junction with restoration of intestine permeability. (iv) Reduction in pro-inflammatory cytokines and, as a consequence, polarization of immune response towards a regulatory phenotype of $\mathrm{T}$ cells.

Some authors have hypothesized that that EEN may exert its effect by depleting harmful bacteria and thus allowing for subsequent re-colonization [148]. Lastly, a recent prospective multicenter cohort study including 43 newly diagnosed children with $C D$ receiving EEN as induction therapy reported decreased microbiota diversity, a reduction in fecal amino acid concentration and a partial regularization of the microbial metabolism of bile acids [144]. Moreover, differences in microbiota and metabolome patterns were observed between responders and non-responders to EEN, postulating the possibility for future prediction of EEN response.

\subsubsection{EEN for Induction of Remission in CD}

In the early 1970s, Voitk et al. [149] reported for the first time in an uncontrolled study the use of Enteral Nutrition (EN) as a management option for active IBD. Thirteen patients awaiting surgery were treated with an elemental diet for an average time of 
22 days. The authors observed improved nutritional states and, unexpectedly, a clinical improvement, with some even avoiding the intended surgery. Subsequently, the first experiences with elemental diet have been reported also in pediatric populations $[150,151]$, showing effectiveness of a 6-week course of elemental diet in restoring growth [150] and inducing remission [151]. Following the above-cited pathfinder studies, several other research lines, including several meta-analyses [120,152], demonstrated the efficacy of EEN for the induction of remission in patients, especially children with CD. According to this recent body of literature, EEN may induce remission in up to $86 \%$ of children with $\mathrm{CD}$, along with a significant decrease in inflammatory biomarkers, such as $\mathrm{C}$ reactive protein (CRP), erythrocyte sedimentation rate (ESR) and FC $[27,153,154]$. Furthermore, in a multicenter prospective inception cohort of newly diagnosed mild-to-moderate CD, Cohen-Dolev et al. [27] showed that, in a propensity-matched score analysis, EEN was superior to corticosteroids for induction of remission $(p=0.05)$ and preservation of linear growth $(p=0.055)$. Efficacy of EEN in the induction of clinical remission in children with CD was further confirmed by Lee et al. [154] also in comparison to biological therapy. Ninety consecutive children with active $C D$ were consequently enrolled in a prospective study, receiving EEN, Infliximab (IFX) or partial enteral nutrition (PEN) for the induction of remission. No differences in clinical response rates between EEN and biologic therapy were observed ( $88 \%$ vs. $84 \%$ ). Even though symptom control is a relevant endpoint for patients with IBD, more recently, treatment strategies have evolved, moving towards targeting the resolution of mucosal inflammation [155]. Several studies demonstrated that EEN is also effective in inducing mucosal healing (MH) within 8-10 weeks of its initiation [156]. In a prospective, open-label study including 26 children with newly diagnosed CD who completed a 6-week EEN course, 15 (58\%) had early endoscopic response, with $11(42 \%)$ of them showing complete MH (Simplified Endoscopic Score for $\mathrm{CD}(\mathrm{SES}-\mathrm{CD})=0)$. The authors reported also complete transmural remission in 3 out of $14(21 \%)$ patients with ileal CD [156]. Additionally, EEN has also outperformed corticosteroid treatment in $\mathrm{MH}$ achievement when the two strategies have been directly compared. In an open-label, randomized controlled trial enrolling 37 children with recently diagnosed active $\mathrm{CD}$, the proportion of patients showing $\mathrm{MH}$ was significantly higher in the EEN group than in the corticosteroid group $(74 \%$ vs. $33 \%, p<0.05)$ [157]. Furthermore, achievement of complete $\mathrm{MH}$ after administration of EEN has been shown to predict also long-term sustained clinical remission [158]. In a prospective single-center study, Grover at al. [158] demonstrated that, among 54 children with mild-to-moderate CD completing a 6-week EEN induction course, achievement of complete MH (SES-CD =0) was associated with higher sustained remission at 3 years compared with active endoscopic disease $(8 / 16,(50 \%)$ vs. $1 / 19,(6 \%), p=0.005)$. Conflicting data regarding the association between EEN efficacy and CD localization are available [31,159-161]. Previous studies suggested a lower efficacy of EEN in patients with isolated colonic disease compared to those with ileal involvement [160]. Subsequent experiences, however, found no differences between isolated colonic disease and ileal or ileocecal involvement [31,161]. In the absence of high-quality evidence, EEN is recommended as the first-line treatment irrespective of CD location [23,44]. Moreover, in cases of the second course of EEN, studies have shown good efficacy, with clinical remission rates ranging from $58 \%$ to $80 \%$. Moreover, two small prospective studies demonstrated that intermittent administration of EEN over one year resulted in a reduction in corticosteroid need and with increased growth velocity $[162,163]$. These data confirm that if the compliance of the patients is maintained, EEN may be successfully reused during the subsequent course of the disease for future relapses [44] (Table 1). 
Table 1. Summary of the studies using EEN as nutritional therapy in children with CD.

\begin{tabular}{|c|c|c|c|c|c|}
\hline First Author & Study Design & Population & $\begin{array}{l}\text { Intervention } \\
\text { (Duration) }\end{array}$ & Control Group & Key Findings \\
\hline Morin [139] & $\mathrm{R}$ & $4 \mathrm{CD}$ with growth failure & $\begin{array}{l}\text { Elemental formula } \\
\text { (6 weeks) }\end{array}$ & $\mathrm{N} / \mathrm{A}$ & $\begin{array}{ll}\text { - } & \text { Clinical efficacy; } \\
\text { - } & \text { Weight and height restoration. }\end{array}$ \\
\hline Sanderson [140] & $\mathrm{P} / \mathrm{RCT}$ & 8 pts with active $C D$ & $\begin{array}{l}\text { Elemental formula } \\
\text { (6 weeks) }\end{array}$ & $8 \mathrm{CD}$ patients treated with CS & $\begin{array}{l}\text { - Significant clinical and biochemical } \\
\text { improvement compared to steroids; } \\
\text { - } \quad \text { Improved body weight and linear growth. }\end{array}$ \\
\hline Cohen-Dolev [24] & $\mathrm{P} / \mathrm{O}$ & $\begin{array}{l}60 \text { patients with newly } \\
\text { diagnosed } C D\end{array}$ & $\begin{array}{l}\text { Any formula } \\
\text { (6-8 weeks) }\end{array}$ & $\begin{array}{l}87 \text { matched patients treated with } \\
\text { CS }\end{array}$ & $\begin{array}{l}\text { - } \quad \text { EEN was superior to CS for inducing remission; } \\
\text { - } \quad \text { EEN trended to superiority for height z-score } \\
\text { compared to CS. }\end{array}$ \\
\hline Levine [142] & $\mathrm{P} / \mathrm{O}$ & $\begin{array}{l}43 \text { patients with newly } \\
\text { diagnosed } C D\end{array}$ & $\begin{array}{l}\text { Any formula } \\
\text { (6-8 weeks) }\end{array}$ & $\begin{array}{l}114 \text { patients treated with CS } \\
29 \text { with 5-ASA }\end{array}$ & $\begin{array}{l}\text { - } \quad \text { EEN and CS effective in normalizing CRP at } \\
\text { week 12; } \\
\text { - } \quad \text { In mild-to-moderate CD, EEN was superior to } \\
\text { CS in normalizing CRP. }\end{array}$ \\
\hline Lee [143] & $\mathrm{P} / \mathrm{O}$ & 22 patients with active $C D$ & $\begin{array}{l}\text { Any formula } \\
\text { (6-8 weeks) }\end{array}$ & $\begin{array}{c}52 \text { patients treated with } \\
\text { anti-TNF- } \alpha \\
16 \text { pts with PEN }+ \text { unrestricted } \\
\text { diet }\end{array}$ & $\begin{array}{l}\text { - Clinical remission rates of EEN and anti-TNF- } \alpha \\
\text { were } 88 \% \text { and } 84 \% \text {, respectively, superior to } \\
\text { those of PEN }(64 \%) \text {; } \\
\text { EEN and anti-TNF- } \alpha \text { but not PEN were effective } \\
\text { in normalizing FC. }\end{array}$ \\
\hline Grover [145] & $\mathrm{P} / \mathrm{O}$ & 26 patients with active $C D$ & $\begin{array}{l}\text { Any formula } \\
\text { (6 weeks) }\end{array}$ & $\mathrm{N} / \mathrm{A}$ & $\begin{array}{l}\text { - } \quad 58 \% \text { of patients achieved at least partial } \mathrm{MH} ; \\
\text { - } 21 \% \text { of pts had complete transmural remission } \\
\text { of ileal CD. }\end{array}$ \\
\hline
\end{tabular}


Table 1. Cont.

\begin{tabular}{|c|c|c|c|c|c|}
\hline First Author & Study Design & Population & $\begin{array}{l}\text { Intervention } \\
\text { (Duration) }\end{array}$ & Control Group & Key Findings \\
\hline Borrelli [146] & $\mathrm{P} / \mathrm{RCT}$ & 19 patients with active $C D$ & $\begin{array}{l}\text { Polymeric formula } \\
\qquad(10 \text { weeks })\end{array}$ & 18 patients treated with CS & $\begin{array}{l}\text { - } \quad \text { No differences were observed in clinical } \\
\text { remission rates; } \\
\text { - } \quad \text { EEN was superior to CS in achieving MH. }\end{array}$ \\
\hline Grover [147] & $\mathrm{P} / \mathrm{O}$ & $\begin{array}{l}54 \text { patients with active } \\
\text { disease }\end{array}$ & $\begin{array}{l}\text { Any formula } \\
\text { (6 weeks) }\end{array}$ & $\mathrm{N} / \mathrm{A}$ & $\begin{array}{l}\text { - Achievement of complete MH (SES-CD) after } \\
\text { EEN course was associated with a long-term } \\
\text { sustained response. }\end{array}$ \\
\hline Rubio [148] & $\mathrm{R}$ & $\begin{array}{l}45 \text { patients with CD who } \\
\text { received oral EEN }\end{array}$ & $\begin{array}{l}\text { Polymeric formula } \\
\text { (8 weeks) }\end{array}$ & $\begin{array}{l}61 \text { patients treated with } \\
\text { continuous EEN }\end{array}$ & $\begin{array}{ll}\text { - } & \text { Similar remission rates; } \\
\text { - } & \text { Similar changes in PCDAI and inflammatory } \\
\text { markers; } \\
\text { - } \quad \text { Higher weight gain in the continuous EEN } \\
\text { group. }\end{array}$ \\
\hline Afzal [150] & $\mathrm{R}$ & 65 patients with active $C D$ & $\begin{array}{l}\text { Polymeric formula } \\
\text { (8 weeks) }\end{array}$ & $\mathrm{N} / \mathrm{A}$ & $\begin{array}{l}\text { - Patients with colonic disease phenotype had } \\
\text { significantly lower remission rates compared to } \\
\text { ileal and ileocolonic localizations. }\end{array}$ \\
\hline Belli [152] & $\mathrm{P}$ & $\begin{array}{l}8 \text { patients with active CD } \\
\text { and growth failure }\end{array}$ & $\begin{array}{l}\text { Polymeric formula } \\
\text { (intermittent administration } \\
\text { over } 1 \text { year) }\end{array}$ & $\begin{array}{l}4 \text { matched CD patients not } \\
\text { treated with EEN }\end{array}$ & $\begin{array}{ll}\text { - } & \text { Intermittent EEN administration showed } \\
\text { significant decrease in CDAI and in CS use; } \\
\text { - } \quad \text { Intermittent EEN showed significant height and } \\
\text { weight improvement }\end{array}$ \\
\hline
\end{tabular}

P: prospective; R: retrospective; O: observational; RCT: randomized controlled trial. 


\subsubsection{EEN for Preoperative Nutritional Optimization in Children with CD}

As previously mentioned, surgery in children with $C D$ is often performed when therapeutic inventory has been depleted, a setting where the onset of postoperative complications is likely to be substantial due to the burden of immunosuppression, hospitalization and malnutrition. Nutritional status is a key element for favorable surgical outcomes [164]. From this perspective, perioperative nutritional therapy has been addressed as a pivotal element when caring for patients with $C D$ who require surgical interventions [118]. A recent systematic literature review performed by a consensus expert panel acknowledged the use of nutritional therapies prior to surgery as a perioperative optimization strategy, despite the paucity of available pediatric data [118]. Indeed, although EEN was first conceived as a preoperative nutritional support, there is a dearth of high-quality studies reporting its systematic use in a preoperative setting $[165,166]$. A recent systematic review explored preoperative nutritional conditioning of patients with CD [167]. Fourteen original studies were identified. Five out of the studies that included a control group [165,168-171], four of which utilized EEN and one parenteral nutrition (PN), reported improved post-surgical outcomes in patients receiving preoperative nutritional support. To date, the only experience reported in pediatric populations is represented by a small case series reported by Harris et al. [172], who assessed the use of EEN as a treatment prior to resection surgery for pediatric CD patients. The authors gathered data on $17 \mathrm{CD}$ pediatric patients who underwent right hemicolectomy. Eight of them received a preoperative course of EEN for a median time of 4 weeks (IQR: $3.7-4.0$ weeks). The median length of hospital stay after surgery was lower in the EEN cohort compared to the non-EEN one (4.5 days versus 6 days, $p=0.03)$. Moreover, the use of EEN was associated with a decreased rate of moderate or severe disease on resection pathology $(5 / 8(62.5 \%)$ versus $9 / 9(100 \%) ; p=0.04)$. No differences in serologic markers were observed, in contrast to previously published adult literature, arguably due to the small sample size. Replication of the results of this study, along with well-designed prospective studies, hopefully RCTs, are deemed to substantiate EEN's role in the preoperative setting of pediatric CD.

\subsubsection{EEN's Effects on Body Mass Composition in Children with CD}

The benefits of EEN extend beyond its ability to induce remission and its capacity to improve anthropometric indices in patients with CD. Gerasimidis et al. [32] performed a prospective study enrolling 17 children with active $C D$ who received EEN, aiming to assess its effects on changes on body composition $[32,173,174]$. The authors reported an improvement in lean body mass after EEN course (lean body mass $z$-score: -2.1 vs. -0.8 before and after treatment, respectively; $p<0.0001$ ) without a significant increase in fat mass [32]. In the same study, also a significant improvement in circulating micronutrients was observed after EEN treatment [32]. A more recent prospective study performed by Strisciuglio et al. [174] reported that EEN was associated with an improvement in both fat free mass (assessed via bioimpedentiometric examination) and bone mineral density (assessed via dual-energy X-ray) in children with newly diagnosed CD. Moreover, the authors observed a significant increase in bone mineral density also at the 1-year follow-up visit, supporting the hypothesis that the reduction in inflammation combined with improvement in nutritional status might be persistent after one year, resulting in ameliorated bone composition and muscle mass. Lastly, a recent sub-study of a randomized clinical trial enrolling children with new-onset mild-to-moderate CD explored the effect of nutritional therapies on bone health. The authors evaluated bone formation and resorption at baseline, at week 12 and at week 24 via serum C-Propeptide of Type I Procollagen (CICP) and type I Collagen N-Telopeptide (NTX), respectively [175]. Bone mineral density was assessed by dual-energy $\mathrm{X}$-ray. The authors reported a significant improvement in CICP, a sensitive marker of bone formation but not of bone mineral density, suggesting that bone improvement is a challenging and a slow process [175]. 


\subsection{Partial Enteral Nutrition (PEN) in $C D$}

PEN refers to the replacement of $35 \%$ to $50 \%$ of habitual food intake with EN feeds while continuing to eat an unrestricted or exclusion diet.

\subsubsection{PEN for the Induction of Remission in CD}

The first RCT specifically designed to investigate the efficacy of PEN (provided as 50\% of elemental formula associated with unrestricted diet) in the induction of remission in children and adolescents with active $C D$ showed unsatisfactory clinical remission rates. Among the 50 children who were randomly assigned to receive either $50 \%$ (PEN) or $100 \%$ (EEN) of their energy requirement as elemental formula for six weeks, clinical remission rates were significantly lower in the PEN group compared to the EEN one (15\% vs. $42 \%$ ) [176]. These results suggest that PEN with access to a free diet is ineffective at relieving inflammation when compared with EEN or IFX, restating the principle of exclusivity. Following the results of this robustly designed, groundbreaking study, research interest in PEN as an alternative induction treatment for CD diminished. More recently, Gupta et al. [177] reported the efficacy of a nutritional treatment protocol involving the administration of $80 \%$ to $90 \%$ of caloric needs through an EN formula overnight and the remaining $10 \%$ to $20 \%$ of the daily energy intake from an unrestricted diet. Among $43 \mathrm{CD}$ pediatric patients included in this retrospective study, induction of remission was achieved in $65 \%$ of them, within a mean treatment duration of 2 months. However, this nutritional protocol led to frequently reported adverse events (up to $65 \%$ of patients) mainly related the use of nocturnal EEN (abdominal distension, sleep disturbances, morning nausea and vomiting, etc.). Nevertheless, these results have not been replicated in more robustly designed studies. Therefore, PEN associated with an unrestricted diet is not currently recommended for the induction of remission of children and adolescents with CD [23].

\subsubsection{Maintenance of Enteral Nutrition (MEN) in CD}

Long-term exclusive enteral nutrition and avoidance of a normal diet is an unfeasible therapeutic option for the maintenance of remission, mainly owing to compliance issues. Maintenance of enteral nutrition (MEN) refers to the use of EN formula, accounting for a percentage of the total caloric requirements, for the maintenance of remission in CD. In a retrospective historical cohort, Wilschanski et al. [178] first reported the effectiveness of supplementary administration of an elemental formula in a cohort of children and adolescents affected by $\mathrm{CD}$. Among 47 pediatric $\mathrm{CD}$ patients who achieved remission after EEN induction, 28 of them continued nocturnal supplementary feeding via a nasogastric tube after resumption of an otherwise unrestricted daytime diet. This subset of patients showed a higher cumulative probability of maintaining clinical remission compared to the group of 19 patients who did not receive PEN $(p=0.005)$. A subsequent retrospective study showed that up to $50 \%$ of patients who received MEN as the only maintenance therapy after a successful course of EEN remained in remission at 1-year follow-up [179]. This response rate did not differ from those obtained with azathioprine $(65 \%)$ or with the combination of MEN and azathioprine (67\%) but was significantly higher than those achieved without maintenance therapy (15\%). Conversely, subsequent studies were not able to confirm the association between MEN and prolonged time to relapse [180-182]. A retrospective study performed by Gavin et al. [181] did not observe a difference in remission length between patients who received MEN and those who remained on a habitual diet $(77 \%$ vs. 78\% 1-year relapse rates). Moreover, in a recent study, Logan et al [182] demonstrated that patients who used MEN during the early period of food reintroduction following a successful course of EEN had lower FC levels compared to those who did not consume MEN. Nonetheless, this effect appeared to be only short-lived as the use of MEN was not associated with prolongation of remission length. Beyond the sole clinical efficacy, the use of MEN has been associated with additional benefits, such as increased height [178] and weight [180] z-scores in children and adolescents. The main evidence to support the benefits of MEN to prolong remission following a successful course of EEN is supported by two 
RCTs performed in adult cohorts in Japan $[183,184]$. Furthermore, a recent meta-analysis investigated the effects of EN in combination with anti-TNF-alpha antibody treatment in adult patients affected by CD [185]. The authors demonstrated, via a systematic review of nine studies, that maintenance of remission was higher in the combination group (70.5\%) than in the non-EN group (53.8\%) [185]. A lack of pediatric evidence in this field exists. Notably, a "dose-dependent" response association appears to exist between the use of MEN and disease relapse [186]. A recent review performed by Gkikas et al. showed that consumption of $>35 \%$ MEN was associated with significantly lower relapse rates compared to the control group, in 8 out of $10(80 \%)$ studies (performed both in children and in adults). Conversely, in all four studies using $\leq 35 \%$ MEN, there was no additional benefit of MEN use in reducing clinical relapse [186]. Arguably, one of the main barriers to MEN consumption is low compliance, mainly due to formula palatability and patient's exhaustion. Interestingly, compliance was not assessed in many of the studies in which MEN was not effective $[180,181]$. Therefore, treatment failure could have been biased by low acceptability of the dietary regimen rather than inadequate efficacy of MEN. The heterogeneity among different studies and the lack of RCTs studies in children remain some of the major limitations in this field of knowledge.

\subsection{Food-Based Therapies in $C D$}

EEN has shown high efficacy in the short term in inducing clinical remission. However, one of its main barriers is represented by monotony of food and taste fatigue experienced by patients. This is one of the major limitations to the wider access and availability of this type of therapy. Several food reintroduction protocols have been attempted after induction of remission using nutritional therapies [187-189]. Among the latter, single-food reintroduction with exclusion of symptom-aggravating foods was the most commonly used protocol [187], which was associated with lower clinical relapse rates, assessed by disease activity indices, compared to patients following an unrestricted diet. Subsequently, Woolner et al. [188] demonstrated that a low-fat, low-fiber diet (LOFFLEX) was associated with similar remission rates when compared to a symptom-alleviating, exclusion diet, arguing a higher acceptability for the patient. The results of these studies, conducted in an era in which markers of mucosal inflammation (endoscopies or FC) were not commonly used, need to be cautiously interpreted, as it remains questionable whether gut inflammation parallels symptoms. Recently, Logan et al. [182] demonstrated a rapid re-exacerbation of inflammation, demonstrated by a rise in FC, during the first 2-3 weeks after the reintroduction of whole food. Hence, re-establishment of a normal diet is associated with reactivation of intestinal inflammation, with MEN showing only a modest effect for the earliest weeks [182].

From this perspective, an understanding of how remission can be maintained through manipulation of diet represents a compelling unmet need. Therefore, it is no surprise that, in the past few years, multiple research groups have attempted to mimic EEN results with nutritional therapeutic strategies allowing access to whole food (Table 2.) 
Table 2. Summary of the studies using food-based therapies in children with CD.

\begin{tabular}{|c|c|c|c|c|c|}
\hline First Author & Study Design & Population & $\begin{array}{c}\text { Intervention } \\
\text { (Duration) }\end{array}$ & Control Group & Key Findings \\
\hline Sigall-Boneh [183] & $\mathrm{R}$ & $\begin{array}{l}47 \text { children and young adult } \\
\text { pts with active CD }\end{array}$ & $\begin{array}{c}\text { CDED + PEN (12 weeks, } n=40) \\
\text { CDED } \\
\text { weeks, } n=7)\end{array}$ & $\mathrm{N} / \mathrm{A}$ & $\begin{array}{c}\text { Clinical remission achieved in } 24 / 34 \\
\text { children and } 9 / 13 \text { adults at wk } 6 \text { and } \\
\text { maintained in } 27 / 33 \text { patients at week } 12 ; \\
\text { Significant fall in clinical disease activity and } \\
\text { inflammatory markers. }\end{array}$ \\
\hline Sigall-Boneh [187] & $\mathrm{R}$ & $\begin{array}{l}21 \text { children and young adult } \\
\text { pts with treatment-refractory } \\
\text { CD }\end{array}$ & $\begin{array}{c}\text { CDED + PEN } \\
(12 \text { weeks, } n=12) \\
\text { CDED } \\
(12 \text { weeks, } n=4) \\
\text { Mod. EEN + CDED } \\
(2+12 \text { weeks, } n=5) \\
\end{array}$ & $\mathrm{N} / \mathrm{A}$ & $\begin{array}{l}\text { 13/21 pts refractory to biologic treatment } \\
\text { achieved clinical remission; } \\
\text { 9/17 of patients failing double biologic } \\
\text { therapy achieved clinical remission; } \\
\text { Significant decrease in serum markers of } \\
\text { inflammation. }\end{array}$ \\
\hline Levine [32] & $\mathrm{P} / \mathrm{RCT}$ & $\begin{array}{l}40 \text { pts with mild-to-moderate } \\
\text { CD }\end{array}$ & $\begin{array}{l}\text { CDED + PEN } \\
\text { (12 weeks) }\end{array}$ & $\begin{array}{l}34 \text { pts with mild-to-moderate } \\
\text { CD treated with EEN }\end{array}$ & $\begin{array}{c}\text { CDED+PEN was equally as effective as EEN } \\
\text { in inducing remission at week } 6 ; \\
\text { CDED+PEN was superior to EEN in } \\
\text { maintaining remission at week } 12 ; \\
\text { CDED+PEN was able to induce rapid } \\
\text { remission (3 weeks); }\end{array}$ \\
\hline Svolos [33] & OL & $\begin{array}{l}5 \text { pts with active CD } \\
\quad(\text { PCDAI } \geq 12.5)\end{array}$ & $\begin{array}{l}\text { CD-TREAT } \\
\text { (8 weeks) }\end{array}$ & $\mathrm{N} / \mathrm{A}$ & $\begin{array}{l}\text { CD-TREAT was able to induce clinical } \\
\text { response in } 80 \% \text { and remission in } 60 \% \text { of } \\
\text { patients; } \\
80 \% \text { of pts showed decrease in fecal } \\
\text { calprotectin }\end{array}$ \\
\hline
\end{tabular}

P: prospective; R: retrospective; O: observational; RCT: randomized controlled trial. 


\subsubsection{Crohn's Disease Exclusion Diet (CDED)}

Among the various food-based therapies, Crohn's Disease Exclusion Diet (CDED) currently represents the most clinically documented for the treatment of active $\mathrm{CD}$. The pathophysiologic paradigm behind CDED is represented by the "bacterial penetration cycle hypothesis", according to which the exposure of intestinal mucosa to adherent or penetrating bacterial species may act as a trigger for the immune system, thus generating inflammation, further barrier breakdown and a subsequent increase in the migration of harmful bacteria through a vicious cycle [190]. CDED was developed to exclude potential harmful foods that have been associated with alterations in host mucous layer [191], dysbiosis [192] and with the development of virulence factors [193] that may allow bacteria to attach to mucosa or to translocate the epithelial barrier. However, CDED is not all about exclusion, as this treatment aims to provide a consistent amount of high-quality protein and to deliver sugars mainly through foods rich in complex carbohydrates. Following these two principles of exclusion and inclusion, natural foods are combined with a variable volume of polymeric formula to meet the nutritional needs and to provide additional amounts of protein, calcium and vitamin D. The CDED nutritional regimen consists of different phases with incremental varieties of food allowed. Phase 1 lasts 6 weeks, aims to induce clinical remission and is the most restrictive one. Besides the elimination of dietary components that trigger inflammation, also fruit and vegetable consumption is restrained during the first phase in order to reduce fiber exposure. PEN is added to provide $50 \%$ of the nutritional needs. During phase 2, which lasts a further 6 weeks, access to food is broadened. To increase the flexibility of the diet and to improve adherence, fiber intake is increased so that almost all fruit and vegetables are allowed during this phase. Moreover, also potentially noxious foods (i.e., gluten, red meat, etc.), whose consumption is not permitted during phase 1 , are gradually reintroduced in a controlled way. PEN consumption is reduced from $50 \%$ to $25 \%$ of the nutritional requirements [194]. Efficacy of CDED was first assessed in a cohort of 47 patients ( 34 children and 13 adults, mean age: $16 \pm 5.6$ years) [195]. Sigall-Boneh et al. [195] reported that such a dietary intervention, based on CDED combined with PEN at 50\%, was able to induce clinical responses in nearly $80 \%$ and clinical remission in up to $70 \%$ of patients with mild-to-moderate CD. They also demonstrated the capacity of such a dietary regimen to normalize CRP in $70 \%$ of patients who achieved clinical remission. The abovementioned results were subsequently confirmed in a 12-week prospective RCT [34]. Seventy-eight children with mild-to-moderate newly diagnosed CD were randomly assigned to a group $(n=40)$ that received CDED plus PEN at $50 \%$ for 6 weeks followed by CDED with PEN at $25 \%$ from week 7 to 12 or a group $(n=38)$ that received EEN for the first 6 weeks and then PEN at $25 \%$ with a free diet [34]. The authors observed no differences in corticosteroid-free remission rates at week $6(75 \%$ in CDED group vs. $59 \%$ in EEN group, $p=0.38$ ). At week 12, the combination of CDED plus PEN was associated with higher remission rates than EEN ( $75.6 \%$ vs. $45.1 \%, p=0.01)$. Additionally, the authors reported that CDED plus PEN was better tolerated than EEN (tolerance rates: $97.5 \%$ vs. $73.6 \%, p=0.002$ ). Furthermore, in a subsequent analysis of the abovementioned RCT, it was demonstrated that CDED + PEN was able to induce a rapid clinical response (at week 3), thus possibly identifying predictors of being in clinical remission at week 6 [196].

The efficacy of CDED was also demonstrated in another, unfortunately common, clinical scenario: the loss of response to biologic agents [197,198]. Sigall-Boneh et al. [199] reported the outcomes of 21 patients ( 11 children and 10 adults) with CD who had experienced loss of response (LoR) to a biologic agent despite dose escalation or combination therapy and received a course of 12 weeks of CDED plus PEN at $50 \%$. At week 6, clinical remission was obtained in $13 / 21$ patients $(61.9 \%)$. Mean CRP levels decreased from $2.8 \pm 3.4 \mathrm{mg} / \mathrm{dL}$ to $0.7 \pm 0.5 \mathrm{mg} / \mathrm{dL}(p=0.005)$ and mean albumin increased from $3.5 \pm 0.6 \mathrm{~g} / \mathrm{dL}$ to $3.8 \pm 0.5 \mathrm{~g} / \mathrm{dL}(p=0.06)$. After the first two phases lasting 12 weeks, the maintenance phase begins. Occasional and controlled access to some type of foods not allowed during the earliest phases is now permitted. The duration of this phase is not 
strictly determined as it is intended to become a stable modification through a healthier lifestyle [194].

\subsubsection{Treatment-with-Eating (CD-TREAT)}

CD-TREAT is an individualized, food-based therapy, which aims to recreate as closely as possible the composition of EEN using ordinary (solid) food through the exclusion of certain dietary components (i.e., gluten, lactose) and the combination of others (macronutrients, vitamins, minerals and fiber) [35]. The objective of such a dietary strategy is to mimic EEN's capacity to modulate the gut microbiota composition [35]. Such properties were first assessed by Svolos et al. [35] in a prospective RCT enrolling 25 healthy subjects, who were randomly allocated to receive either EEN or CD-TREAT for 7 days, each with a 2 -week washout in between. The authors reported that the fecal microbiota along with fecal metabolome significantly changed in the same direction for the two dietary strategies, with several parallel changes in metabolites and species [35]. The effects observed in healthy subjects were subsequently replicated in gut inflammation animal models [35]. Lastly, CD-TREAT has been administered in a course of 8 weeks to five children with active CD in a pilot study, showing efficacy in inducing clinical remission and in reducing FC [35]. Although promising, these proof-of-concept data need to be confirmed in an ongoing, adequately powered RCT [200].

\section{Conclusions}

Nutrition and growth are peculiar features of pediatric age. When dealing with children and adolescents affected by $\mathrm{CD}$, the comprehensive management of the disease must extend beyond tight control of inflammation and cannot refrain from enhancement of nutritional status. Indeed, results from the recent literature have shown that sarcopenia and undernutrition are associated with a poorer disease course, complications and to a lower response to pharmacological therapies, whose weaponry is expanding yet currently limited in pediatric populations. Moreover, clinicians caring for children and adolescents with $C D$ need to deal with the developmental milestones, such as growth and puberty, distinctive of this delicate period and with the expected long-lasting course of the disease. From this perspective, targeting simultaneously the nutritional deficiencies, which commonly occur in children with $C D$, with the resolution of gut inflammation and the correction of intestinal dysbiosis may provide synergistic benefits while minimizing risks and allowing sparing of the pharmacological weaponry. Such an intriguing research line requires well-designed studies in order to unravel the full potential of nutritional and dietary therapies for CD. Hopefully, in the foreseeable future, integration of the "omics" datasets using a system biology-based approach will help to elucidate the complex bond between diet and host along with allowing the development of novel precision medicine applications [201].

Author Contributions: L.S. and P.L. designed and drafted the manuscript. P.L. oversaw the project and checked the integrity of the work. All authors have read and agreed to the published version of the manuscript.

Funding: This work was not supported by any grant or funding sources.

Institutional Review Board Statement: Not applicable.

Informed Consent Statement: Not applicable.

Data Availability Statement: Not applicable.

Conflicts of Interest: L.S. has no conflict of interest to declare. P.L. received consultation fees for lectures from Abbvie, Jansen, Nestle Health Science, Pfizer, and Sandoz. 


\section{References}

1. Fumery, M.; Pariente, B.; Sarter, H.; Savoye, G.; Spyckerelle, C.; Djeddi, D.; Mouterde, O.; Bouguen, G.; Ley, D.; Peneau, A.; et al. Long-term outcome of pediatric-onset Crohn's disease: A population-based cohort study. Dig. Liver Dis. 2019, 51, 496-502. [CrossRef] [PubMed]

2. Duricova, D.; Fumery, M.; Annese, V.; Lakatos, P.L.; Peyrin-Biroulet, L.; Gower-Rousseau, C. The natural history of Crohn's disease in children: A review of population-based studies. Eur. J. Gastroenterol. Hepatol. 2017, 29, 10. [CrossRef] [PubMed]

3. Ghione, S.; Sarter, H.; Fumery, M.; Armengol-Debeir, L.; Savoye, G.; Ley, D.; Spyckerelle, C.; Pariente, B.; Peyrin-Biroulet, L.; Turck, D.; et al. Dramatic Increase in Incidence of Ulcerative Colitis and Crohn's Disease (1988-2011): A Population-Based Study of French Adolescents. Am. J. Gastroenterol. 2018, 113, 265-272. [CrossRef] [PubMed]

4. $\quad$ E Roberts, S.; Thorne, K.; Thapar, N.; Broekaert, I.; A Benninga, M.; Dolinsek, J.; Mas, E.; Miele, E.; Orel, R.; Pienar, C.; et al. A Systematic Review and Meta-analysis of Paediatric Inflammatory Bowel Disease Incidence and Prevalence Across Europe. J. Crohn's Colitis 2020, 14, 1119-1148. [CrossRef]

5. Van Limbergen, J.; Russell, R.K.; Drummond, H.E.; Aldhous, M.C.; Round, N.K.; Nimmo, E.R.; Smith, L.; Gillett, P.M.; McGrogan, P.; Weaver, L.T.; et al. Definition of Phenotypic Characteristics of Childhood-Onset Inflammatory Bowel Disease. Gastroenterology 2008, 135, 1114-1122. [CrossRef] [PubMed]

6. Duricova, D.; Burisch, J.; Jess, T.; Gower-Rousseau, C.; Lakatos, P.L. Age-related differences in presentation and course of inflammatory bowel disease: An update on the population-based literature. J. Crohn's Colitis 2014, 8, 1351-1361. [CrossRef]

7. Jakobsen, C.; Bartek, J., Jr.; Wewer, V.; Vind, I.; Munkholm, P.; Groen, R.; Paerregaard, A. Differences in phenotype and disease course in adult and paediatric inflammatory bowel disease-A population-based study: Differences between paediatric and adult IBD. Aliment. Pharmacol. Ther. 2011, 34, 1217-1224. [CrossRef]

8. Kelsen, J.; Baldassano, R.N. Inflammatory bowel disease: The difference between children and adults. Inflamm. Bowel Dis. 2008, 14, S9-S11. [CrossRef]

9. Torres, J.; Mehandru, S.; Colombel, J.-F.; Peyrin-Biroulet, L. Crohn's disease. Lancet 2017, 389, 1741-1755. [CrossRef]

10. Huang, H.; International Inflammatory Bowel Disease Genetics Consortium; Fang, M.; Jostins, L.; Mirkov, M.U.; Boucher, G.; Anderson, C.A.; Andersen, V.; Cleynen, I.; Cortes, A.; et al. Fine-mapping inflammatory bowel disease loci to single-variant resolution. Nat. Cell Biol. 2017, 547, 173-178. [CrossRef] [PubMed]

11. Park, J.-H.; Wacholder, S.; Gail, M.H.; Peters, U.; Jacobs, K.B.; Chanock, S.J.; Chatterjee, N. Estimation of effect size distribution from genome-wide association studies and implications for future discoveries. Nat. Genet. 2010, 42, 570-575. [CrossRef] [PubMed]

12. A Peters, L.; Perrigoue, J.; Mortha, A.; Iuga, A.; Song, W.-M.; Neiman, E.M.; Llewellyn, S.R.; Di Narzo, A.; A Kidd, B.; E Telesco, S.; et al. A functional genomics predictive network model identifies regulators of inflammatory bowel disease. Nat. Genet. 2017, 49, 1437-1449. [CrossRef]

13. Levine, A.; Boneh, R.S.; Wine, E. Evolving role of diet in the pathogenesis and treatment of inflammatory bowel diseases. Gut 2018, 67, 1726-1738. [CrossRef]

14. Kaplan, G.G.; Windsor, J.W. The four epidemiological stages in the global evolution of inflammatory bowel disease. Nat. Rev. Gastroenterol. Hepatol. 2021, 18, 56-66. [CrossRef] [PubMed]

15. De Filippo, C.; Cavalieri, D.; Di Paola, M.; Ramazzotti, M.; Poullet, J.B.; Massart, S.; Collini, S.; Pieraccini, G.; Lionetti, P. Impact of diet in shaping gut microbiota revealed by a comparative study in children from Europe and rural Africa. Proc. Natl. Acad. Sci. USA 2010, 107, 14691-14696. [CrossRef]

16. De Filippo, C.; Di Paola, M.; Ramazzotti, M.; Albanese, D.; Pieraccini, G.; Banci, E.; Miglietta, F.; Cavalieri, D.; Lionetti, P. Diet, Environments, and Gut Microbiota. A Preliminary Investigation in Children Living in Rural and Urban Burkina Faso and Italy. Front. Microbiol. 2017, 8, 1979. [CrossRef] [PubMed]

17. Desai, M.S.; Seekatz, A.M.; Koropatkin, N.M.; Kamada, N.; Hickey, C.A.; Wolter, M.; Pudlo, N.A.; Kitamoto, S.; Terrapon, N.; Muller, A.; et al. A Dietary Fiber-Deprived Gut Microbiota Degrades the Colonic Mucus Barrier and Enhances Pathogen Susceptibility. Cell 2016, 167, 1339-1353.e21. [CrossRef]

18. Martinez-Medina, M.; Denizot, J.; Dreux, N.; Robin, F.; Billard, E.; Bonnet, R.; Barnich, N. Western diet induces dysbiosis with increased E coli in CEABAC10 mice, alters host barrier function favouring AIEC colonisation. Gut 2014, 63, 116-124. [CrossRef]

19. Statovci, D.; Aguilera, M.; MacSharry, J.; Melgar, S. The Impact of Western Diet and Nutrients on the Microbiota and Immune Response at Mucosal Interfaces. Front. Immunol. 2017, 8, 838. [CrossRef]

20. Dong, J.; Chen, Y.; Tang, Y.; Xu, F.; Yu, C.; Li, Y.; Pankaj, P.; Dai, N. Body Mass Index Is Associated with Inflammatory Bowel Disease: A Systematic Review and Meta-Analysis. PLoS ONE 2015, 10, e0144872. [CrossRef]

21. Yerushalmy-Feler, A.; Galai, T.; Moran-Lev, H.; Ben-Tov, A.; Dali-Levy, M.; Weintraub, Y.; Amir, A.; Cohen, S. BMI in the lower and upper quartiles at diagnosis and at 1-year follow-up is significantly associated with higher risk of disease exacerbation in pediatric inflammatory bowel disease. Eur. J. Nucl. Med. Mol. Imaging 2021, 180, 21-29. [CrossRef]

22. Nguyen, G.C.; Munsell, M.; Harris, M.L. Nationwide prevalence and prognostic significance of clinically diagnosable proteincalorie malnutrition in hospitalized inflammatory bowel disease patients. Inflamm. Bowel Dis. 2008, 14, 1105-1111. [CrossRef] [PubMed]

23. Van Rheenen, P.F.; Aloi, M.; Assa, A.; Bronsky, J.; Escher, J.C.; Fagerberg, U.L.; Gasparetto, M.; Gerasimidis, K.; Griffiths, A.; Henderson, P.; et al. The Medical Management of Paediatric Crohn's Disease: An ECCO-ESPGHAN Guideline Update. J. Crohn's Colitis 2021, 15, 171-194. [CrossRef] [PubMed] 
24. Kugathasan, S.; A Denson, L.; Walters, T.D.; Kim, M.-O.; Marigorta, U.M.; Schirmer, M.; Mondal, K.; Liu, C.; Griffiths, A.; Noe, J.D.; et al. Prediction of complicated disease course for children newly diagnosed with Crohn's disease: A multicentre inception cohort study. Lancet 2017, 389, 1710-1718. [CrossRef]

25. Ford, A.C.; Peyrin-Biroulet, L. Opportunistic Infections With Anti-Tumor Necrosis Factor- $\alpha$ Therapy in Inflammatory Bowel Disease: Meta-Analysis of Randomized Controlled Trials. Am. J. Gastroenterol. 2013, 108, 1268-1276. [CrossRef]

26. Magro, F.; Peyrin-Biroulet, L.; Sokol, H.; Aldeger, X.; Costa, A.; Higgins, P.D.; Joyce, J.C.; Katsanos, K.H.; Lopez, A.; De Xaxars, T.M.; et al. Extra-intestinal malignancies in inflammatory bowel disease: Results of the 3rd ECCO Pathogenesis Scientific Workshop (III). J. Crohn's Colitis 2014, 8, 31-44. [CrossRef]

27. Cohen-Dolev, N.; Sladek, M.; Hussey, S.; Turner, D.; Veres, G.; Koletzko, S.; Levine, A. Differences in Outcomes Over Time with Exclusive Enteral Nutrition Compared With Steroids in Children With Mild to Moderate Crohn's Disease: Results From the GROWTH CD Study. J. Crohn's Colitis 2018, 12, 306-312. [CrossRef]

28. Grover, Z.; Lewindon, P. Two-Year Outcomes After Exclusive Enteral Nutrition Induction Are Superior to Corticosteroids in Pediatric Crohn's Disease Treated Early with Thiopurines. Dig. Dis. Sci. 2015, 60, 3069-3074. [CrossRef] [PubMed]

29. Scarallo, L. Mucosal and Histologic Healing in children with Inflammatory Bowel Disease treated with anti-Tumor Necrosis Factor-alpha. J. Pediatr. Gastroenterol. Nutr. 2021, 72, 728-735. [CrossRef] [PubMed]

30. Qiu, Y.; Chen, B.-L.; Mao, R.; Zhang, S.-H.; He, Y.; Zeng, Z.-R.; Ben-Horin, S.; Chen, M.-H. Systematic review with meta-analysis: Loss of response and requirement of anti-TNF $\alpha$ dose intensification in Crohn's disease. J. Gastroenterol. 2017, 52, 535-554. [CrossRef] [PubMed]

31. Rubio, A. The efficacy of exclusive nutritional therapy in paediatric Crohn's disease, comparing fractionated oral vs. continuous enteral feeding: Oral vs. continuous enteral nutrition for CD in children. Aliment. Pharmacol. Ther. 2011, 33, 1332-1339. [CrossRef] [PubMed]

32. Gerasimidis, K. Impact of exclusive enteral nutrition on body composition and circulating micronutrients in plasma and erythrocytes of children with active Crohn's disease. Inflamm. Bowel Dis. 2012, 18, 1672-1681. [CrossRef]

33. Stewart, M.; Day, A.S.; Otley, A. Physician Attitudes and Practices of Enteral Nutrition as Primary Treatment of Paediatric Crohn Disease in North America. J. Pediatr. Gastroenterol. Nutr. 2011, 52, 38-42. [CrossRef] [PubMed]

34. Levine, A.; Wine, E.; Assa, A.; Boneh, R.S.; Shaoul, R.; Kori, M.; Cohen, S.; Peleg, S.; Shamaly, H.; On, A.; et al. Crohn's Disease Exclusion Diet Plus Partial Enteral Nutrition Induces Sustained Remission in a Randomized Controlled Trial. Gastroenterology 2019, 157, 440-450.e8. [CrossRef]

35. Svolos, V.; Hansen, R.; Nichols, B.; Quince, C.; Ijaz, U.Z.; Papadopoulou, R.T.; Edwards, C.A.; Watson, D.; Alghamdi, A.; Brejnrod, A.; et al. Treatment of Active Crohn's Disease With an Ordinary Food-based Diet That Replicates Exclusive Enteral Nutrition. Gastroenterology 2019, 156, 1354-1367.e6. [CrossRef] [PubMed]

36. Hartman, C.; Eliakim, R.; Shamir, R. Nutritional status and nutritional therapy in inflammatory bowel diseases. World J. Gastroenterol. 2009, 15, 2570-2578. [CrossRef] [PubMed]

37. Goh, J.; O'Morain, C.A. Nutrition and adult inflammatory bowel disease. Aliment. Pharm. Ther. 2003, 14, 307-320. [CrossRef]

38. Balestrieri, P.; Ribolsi, M.; Guarino, M.P.L.; Emerenziani, S.; Altomare, A.; Cicala, M. Nutritional Aspects in Inflammatory Bowel Diseases. Nutrients 2020, 12, 372. [CrossRef]

39. Sanderson, I.R. Growth problems in children with IBD. Nat. Rev. Gastroenterol. Hepatol. 2014, 11, 601-610. [CrossRef] [PubMed]

40. Vasudevan, A.; Parthasarathy, N.; Con, D.; Nicolaides, S.; Apostolov, R.; Chauhan, A.; Bishara, M.; Luber, R.P.; Joshi, N.; Wan, A.; et al. Thiopurines vs methotrexate: Comparing tolerability and discontinuation rates in the treatment of inflammatory bowel disease. Aliment. Pharmacol. Ther. 2020, 52, 1174-1184. [CrossRef] [PubMed]

41. Jowett, S.L.; Seal, C.J.; Phillips, E.; Gregory, W.; Barton, J.; Welfare, M.R. Dietary beliefs of people with ulcerative colitis and their effect on relapse and nutrient intake. Clin. Nutr. 2004, 23, 161-170. [CrossRef]

42. Guerreiro, C.S.; Cravo, M.; Costa, A.R.; Miranda, A.; Tavares, L.; Moura-Santos, P.; Marquesvidal, P.; Leitão, C.N. A Comprehensive Approach to Evaluate Nutritional Status in Crohn's Patients in the Era of Biologic Therapy: A Case-Control Study. Am. J. Gastroenterol. 2007, 102, 2551-2556. [CrossRef]

43. Martini, E.; Krug, S.M.; Siegmund, B.; Neurath, M.F.; Becker, C. Mend Your Fences. Cell. Mol. Gastroenterol. Hepatol. 2017, 4, 33-46. [CrossRef] [PubMed]

44. Miele, E.; Shamir, R.; Aloi, M.; Assa, A.; Braegger, C.; Bronsky, J.; de Ridder, L.; Escher, J.C.; Hojsak, I.; Kolaček, S.; et al. Nutrition in Pediatric Inflammatory Bowel Disease: A Position Paper on Behalf of the Porto Inflammatory Bowel Disease Group of the European Society of Pediatric Gastroenterology, Hepatology and Nutrition. J. Pediatr. Gastroenterol. Nutr. 2018, 66, 687-708. [CrossRef] [PubMed]

45. Varille, V.; Cézard, J.P.; De Lagausie, P.; Bellaiche, M.; Tounian, P.; Besnard, M.; Faure, C.; Aigrain, Y.; Girardet, J.P.; Navarro, J. Resting Energy Expenditure before and after Surgical Resection of Gut Lesions in Pediatric Crohn's Disease. J. Pediatr. Gastroenterol. Nutr. 1996, 23, 13-19. [CrossRef] [PubMed]

46. Wiskin, A.E.; Wootton, S.A.; Culliford, D.J.; Afzal, N.A.; Jackson, A.A.; Beattie, R.M. Impact of disease activity on resting energy expenditure in children with inflammatory bowel disease. Clin. Nutr. 2009, 28, 652-656. [CrossRef]

47. A Sentongo, T.; Semeao, E.J.; A Piccoli, D.; A Stallings, V.; Zemel, B.S. Growth, Body Composition, and Nutritional Status in Children and Adolescents With Crohn's Disease. J. Pediatr. Gastroenterol. Nutr. 2000, 31, 33-40. [CrossRef] 
48. Kanof, M.E.; Lake, A.M.; Bayless, T.M. Decreased Height Velocity in Children and Adolescents Before the Diagnosis of Crohn's Disease. Gastroenterology 1988, 95, 1523-1527. [CrossRef]

49. Vasseur, F.; Gower-Rousseau, C.; Vernier-Massouille, G.; Dupas, J.L.; Merle, V.; Merlin, B.; Lerebours, E.; Savoye, G.; Salomez, J.L.; Cortot, A.; et al. Nutritional Status and Growth in Pediatric Crohn's Disease: A Population-Based Study. Am. J. Gastroenterol. 2010, 105, 1893-1900. [CrossRef]

50. Pfefferkorn, M.; Burke, G.; Griffiths, A.; Markowitz, J.; Rosh, J.; Mack, D.; Otley, A.; Kugathasan, S.; Evans, J.; Bousvaros, A.; et al . Growth Abnormalities Persist in Newly Diagnosed Children With Crohn Disease Despite Current Treatment Paradigms. J. Pediatr. Gastroenterol. Nutr. 2009, 48, 168-174. [CrossRef]

51. Lee, J.; Escher, J.; Shuman, M.; Forbes, P.; Delemarre, L.; Harr, B.; Kruijer, M.; Moret, M.; Allende-Richter, S.; Grand, R. Final adult height of children with inflammatory bowel disease is predicted by parental height and patient minimum height Z-score. Inflamm. Bowel Dis. 2010, 16, 1669-1677. [CrossRef] [PubMed]

52. Yerushalmy-Feler, A.; Ben-Tov, A.; Weintraub, Y.; Amir, A.; Galai, T.; Moran-Lev, H.; Cohen, S. High and low body mass index may predict severe disease course in children with inflammatory bowel disease. Scand. J. Gastroenterol. 2018, 53, 708-713. [CrossRef] [PubMed]

53. Thangarajah, D.; Hyde, M.J.; Konteti, V.K.S.; Santhakumaran, S.; Frost, G.; Fell, J.M.E. Systematic review: Body composition in children with inflammatory bowel disease. Aliment. Pharmacol. Ther. 2015, 42, 142-157. [CrossRef]

54. Houttu, N.; Kalliomäki, M.; Grönlund, M.-M.; Niinikoski, H.; Nermes, M.; Laitinen, K. Body composition in children with chronic inflammatory diseases: A systematic review. Clin. Nutr. 2020, 39, 2647-2662. [CrossRef] [PubMed]

55. Ward, L.M.; Ma, J.; Rauch, F.; Benchimol, E.I.; Hay, J.; Leonard, M.B.; Matzinger, M.A.; Shenouda, N.; Lentle, B.; Cosgrove, H.; et al. Musculoskeletal health in newly diagnosed children with Crohn's disease. Osteoporos. Int. 2017, 28, 3169-3177. [CrossRef]

56. Sylvester, F.A.; Leopold, S.; Lincoln, M.; Hyams, J.S.; Griffiths, A.M.; Lerer, T. A Two-Year Longitudinal Study of Persistent Lean Tissue Deficits in Children With Crohn's Disease. Clin. Gastroenterol. Hepatol. 2009, 7, 452-455. [CrossRef]

57. Werkstetter, K.J.; Ullrich, J.; Schatz, S.B.; Prell, C.; Koletzko, B.; Koletzko, S. Lean body mass, physical activity and quality of life in paediatric patients with inflammatory bowel disease and in healthy controls. J. Crohn's Coliti 2012, 6, 665-673. [CrossRef] [PubMed]

58. Wolfe, R.R. The underappreciated role of muscle in health and disease. Am. J. Clin. Nutr. 2006, 84, 475-482. [CrossRef]

59. Gerasimidis, K.; McGrogan, P.; Edwards, C.A. The aetiology and impact of malnutrition in paediatric inflammatory bowel disease. J. Hum. Nutr. Diet. 2011, 24, 313-326. [CrossRef]

60. Holt, D.Q.; Varma, P.; Strauss, B.J.G.; Rajadurai, A.S.; Moore, G.T. Low muscle mass at initiation of anti-TNF therapy for inflammatory bowel disease is associated with early treatment failure: A retrospective analysis. Eur. J. Clin. Nutr. 2017, 71, 773-777. [CrossRef]

61. Murthy, S.K.; Begum, J.; I Benchimol, E.; Bernstein, C.N.; Kaplan, G.G.; McCurdy, J.D.; Singh, H.; Targownik, L.; Taljaard, M. Introduction of anti-TNF therapy has not yielded expected declines in hospitalisation and intestinal resection rates in inflammatory bowel diseases: A population-based interrupted time series study. Gut 2020, 69, 274-282. [CrossRef] [PubMed]

62. Alves, A.; Panis, Y.; Bouhnik, Y.; Pocard, M.; Vicaut, E.; Valleur, P. Risk Factors for Intra-Abdominal Septic Complications After a First Ileocecal Resection for Crohn's Disease: A Multivariate Analysis in 161 Consecutive Patients. Dis. Colon Rectum 2007, 50, 331-336. [CrossRef] [PubMed]

63. Ryan, E. Sarcopenia and Inflammatory Bowel Disease: A Systematic Review. Inflamm. Bowel Dis. 2019, 25, 67-73. [CrossRef]

64. Limdi, J.K.; Aggarwal, D.; McLaughlin, J.T. Dietary Practices and Beliefs in Patients with Inflammatory Bowel Disease. Inflamm. Bowel Dis. 2016, 22, 164-170. [CrossRef] [PubMed]

65. Hartman, C.; Marderfeld, L.; Davidson, K.; Mozer-Glassberg, Y.; Poraz, I.; Silbermintz, A.; Zevit, N.; Shamir, R. Food Intake Adequacy in Children and Adolescents With Inflammatory Bowel Disease. J. Pediatr. Gastroenterol. Nutr. 2016, 63, 437-444. [CrossRef]

66. Thomas, A.G.; Miller, V.; Taylor, F.; Maycock, P.; Scrimgeour, C.M.; Rennie, M.J. Whole body protein turnover in childhood Crohn's disease. Gut 1992, 33, 675-677. [CrossRef] [PubMed]

67. Steiner, S.J.; Noe, J.D.; Denne, S.C. Corticosteroids Increase Protein Breakdown and Loss in Newly Diagnosed Pediatric Crohn Disease. Pediatr. Res. 2011, 70, 484-488. [CrossRef] [PubMed]

68. Steiner, S.J.; Pfefferkorn, M.D.; Fitzgerald, J.F.; Denne, S.C. Protein and energy metabolism response to the initial dose of infliximab in children with Crohn's disease. Inflamm. Bowel Dis. 2007, 13, 737-744. [CrossRef]

69. Wiskin, A.E.; Fleming, B.J.; Wootton, S.A.; Beattie, R.M. Anaemia and iron deficiency in children with inflammatory bowel disease. J. Crohn's Colitis 2012, 6, 687-691. [CrossRef] [PubMed]

70. Goyal, A.; Zheng, Y.; Albenberg, L.G.; Stoner, N.L.; Hart, L.; Alkhouri, R.; Hampson, K.; Ali, S.; Cho-Dorado, M.; Goyal, R.K.; et al. Anemia in Children With Inflammatory Bowel Disease: A Position Paper by the IBD Committee of the North American Society of Pediatric Gastroenterology, Hepatology and Nutrition. J. Pediatr. Gastroenterol. Nutr. 2020, 71, 563-582. [CrossRef] [PubMed]

71. Pels, L.P.; Van de Vijver, E.; Waalkens, H.J.; Uitentuis, J.; Jong, G.G.-D.; van Overbeek, L.A.; Norbruis, O.F.; Rings, E.H.; van Rheenen, P.F. Slow Hematological Recovery in Children With IBD-associated Anemia in Cases of "Expectant Management. " J. Pediatr. Gastroenterol. Nutr. 2010, 51, 708-713. [CrossRef] [PubMed] 
72. Gerasimidis, K. The Epidemiology of Anemia in Pediatric Inflammatory Bowel Disease: Prevalence and Associated Factors at Diagnosis and Follow-up and the Impact of Exclusive Enteral Nutrition. Inflamm. Bowel Dis. 2013, 19, 2411-2422. [CrossRef] [PubMed]

73. Goodhand, J.R.; Kamperidis, N.; Rao, A.; Laskaratos, F.; McDermott, A.; Wahed, M.; Naik, S.; Croft, N.M.; Lindsay, J.O.; Sanderson, I.R.; et al. Prevalence and management of anemia in children, adolescents, and adults with inflammatory bowel disease. Inflamm. Bowel Dis. 2012, 18, 513-519. [CrossRef] [PubMed]

74. Sjöberg, D. Anemia in a population-based IBD cohort (ICURE): Still high prevalence after 1 year, especially among pediatric patients. Inflamm. Bowel Dis. 2014, 20, 2266-2270. [CrossRef]

75. Carvalho, F.S.G.; de Medeiros, I.A.; Antunes, H. Prevalence of iron deficiency anemia and iron deficiency in a pediatric population with inflammatory bowel disease. Scand. J. Gastroenterol. 2017, 52, 1099-1103. [CrossRef] [PubMed]

76. Stein, J.; Hartmann, F.; Dignass, A.U. Diagnosis and management of iron deficiency anemia in patients with IBD. Nat. Rev. Gastroenterol. Hepatol. 2010, 7, 599-610. [CrossRef] [PubMed]

77. Aljomah, G.; Baker, S.S.; Schmidt, K.; Alkhouri, R.; Kozielski, R.; Zhu, L.; Baker, R.D. Anemia in Pediatric Inflammatory Bowel Disease. J. Pediatr. Gastroenterol. Nutr. 2018, 67, 351-355. [CrossRef]

78. Tolkien, Z.; Stecher, L.; Mander, A.P.; Pereira, D.I.A.; Powell, J.J. Ferrous Sulfate Supplementation Causes Significant Gastrointestinal Side-Effects in Adults: A Systematic Review and Meta-Analysis. PLoS ONE 2015, 10, e0117383. [CrossRef]

79. Gargallo-Puyuelo, C.J.; Alfambra, E.; García-Erce, J.A.; Gomollon, F. Iron Treatment May Be Difficult in Inflammatory Diseases: Inflammatory Bowel Disease as a Paradigm. Nutrients 2018, 10, 1959. [CrossRef] [PubMed]

80. Jaeggi, T.; Kortman, G.A.M.; Moretti, D.; Chassard, C.; Holding, P.; Dostal, A.; Boekhorst, J.; Timmerman, H.M.; Swinkels, D.W.; Tjalsma, H.; et al. Iron fortification adversely affects the gut microbiome, increases pathogen abundance and induces intestinal inflammation in Kenyan infants. Gut 2015, 64, 731-742. [CrossRef]

81. Weiss, G. Dietary iron supplementation: A proinflammatory attack on the intestine? Gut 2014, 64, 696-697. [CrossRef] [PubMed]

82. Cummings, J.F.; Fraser, A.; Stansfield, C.; Beales, I.; Sebastian, S.; Hoque, S. Ferric maltol Real-world Effectiveness Study in Hospital practice (FRESH): Clinical characteristics and outcomes of patients with inflammatory bowel disease receiving ferric maltol for iron-deficiency anaemia in the UK. BMJ Open Gastroenterol. 2021, 8, e000530. [CrossRef]

83. Lee, T.; Clavel, T.; Smirnov, K.; Schmidt, A.; Lagkouvardos, I.; Walker, A.; Lucio, M.; Michalke, B.; Schmitt-Kopplin, P.; Fedorak, R.; et al. Oral versus intravenous iron replacement therapy distinctly alters the gut microbiota and metabolome in patients with IBD. Gut 2016, 66, 863-871. [CrossRef] [PubMed]

84. Rampton, D.S.; Goodhand, J.R.; Joshi, N.M.; Karim, A.-B.; Koodun, Y.; Barakat, F.M.; Macken, L.; Ward, D.G.; Iqbal, T.H.; Epstein, J.; et al. Oral Iron Treatment Response and Predictors in Anaemic Adolescents and Adults with IBD: A Prospective Controlled Open-Label Trial. J. Crohn's Colitis 2016, 11, 706-715. [CrossRef] [PubMed]

85. Chertow, G.M.; Mason, P.D.; Vaage-Nilsen, O.; Ahlmén, J. Update on adverse drug events associated with parenteral iron. Nephrol. Dial. Transplant. 2006, 21, 378-382. [CrossRef] [PubMed]

86. Mamula, P.; Piccoli, D.A.; Peck, S.N.; Markowitz, J.E.; Baldassano, R.N. Total Dose Intravenous Infusion of Iron Dextran for Iron-Deficiency Anemia in Children With Inflammatory Bowel Disease. J. Pediatr. Gastroenterol. Nutr. 2002, 34, 286-290. [CrossRef]

87. Stein, R.E.; Plantz, K.; Maxwell, E.C.; Mamula, P.; Baldassano, R.N. Intravenous Iron Sucrose for Treatment of Iron Deficiency Anemia in Pediatric Inflammatory Bowel Disease. J. Pediatr. Gastroenterol. Nutr. 2018, 66, e51-e55. [CrossRef]

88. Papadopoulos, M. Safety and efficacy of parenteral iron in children with inflammatory bowel disease: Safety and efficacy of parenteral iron in children with IBD. Br. J. Clin. Pharmacol. 2018, 84, 694-699. [CrossRef] [PubMed]

89. Carman, N.; Muir, R.; Lewindon, P. Ferric carboxymaltose in the treatment of iron deficiency in pediatric inflammatory bowel disease. Transl. Pediatr. 2019, 8, 28-34. [CrossRef] [PubMed]

90. Powers, J.M.; Shamoun, M.; McCavit, T.L.; Adix, L.; Buchanan, G.R. Intravenous Ferric Carboxymaltose in Children with Iron Deficiency Anemia Who Respond Poorly to Oral Iron. J. Pediatr. 2017, 180, 212-216. [CrossRef] [PubMed]

91. Savage, D.G.; Lindenbaum, J.; Stabler, S.P.; Allen, R.H. Sensitivity of serum methylmalonic acid and total homocysteine determinations for diagnosing cobalamin and folate deficiencies. Am. J. Med. 1994, 96, 239-246. [CrossRef]

92. Battat, R.; Kopylov, U.; Szilagyi, A.; Saxena, A.; Rosenblatt, D.S.; Warner, M.; Bessissow, T.; Seidman, E.; Bitton, A. Vitamin B12 Deficiency in Inflammatory Bowel Disease. Inflamm. Bowel Dis. 2014, 20, 1120-1128. [CrossRef]

93. Fritz, J.; Walia, C.; Elkadri, A.; Pipkorn, R.; Dunn, R.K.; Sieracki, R.; Goday, P.S.; Cabrera, J.M. A Systematic Review of Micronutrient Deficiencies in Pediatric Inflammatory Bowel Disease. Inflamm. Bowel Dis. 2018, 25, 445-459. [CrossRef] [PubMed]

94. Yakut, M.; Üstün, Y.; Kabaçam, G.; Soykan, I. Serum vitamin B12 and folate status in patients with inflammatory bowel diseases. Eur. J. Intern. Med. 2010, 21, 320-323. [CrossRef]

95. Vagianos, K.; Bernstein, C.N. Homocysteinemia and B vitamin status among adult patients with inflammatory bowel disease: A one-year prospective follow-up study. Inflamm. Bowel Dis. 2012, 18, 718-724. [CrossRef] [PubMed]

96. Bermejo, F.; Algaba, A.; Guerra, I.; Chaparro, M.; De-La-Poza, G.; Valer, P.; Piqueras, B.; Bermejo, A.; García-Alonso, J.; Pérez, M.-J.; et al. Should we monitor vitamin B12and folate levels in Crohn's disease patients? Scand. J. Gastroenterol. 2013, 48, 1272-1277. [CrossRef] [PubMed]

97. Lopes, M.B.; Rocha, R.; Lyra, A.C.; Oliveira, V.R.; Coqueiro, F.G.; Almeida, N.S.; Valois, S.S.; Santana, G.O. Restriction of dairy products; a reality in inflammatory bowel disease patients. Nutr. Hosp. 2014, 29, 575-581. [CrossRef] 
98. Filippi, J.; Al-Jaouni, R.; Wiroth, J.-B.; Hébuterne, X.; Schneider, S.M. Nutritional deficiencies in patients with Crohn's disease in remission. Inflamm. Bowel Dis. 2006, 12, 185-191. [CrossRef] [PubMed]

99. Paganelli, M.; Albanese, C.V.; Borrelli, O.; Civitelli, F.; Canitano, N.; Viola, F.; Passariello, R.; Cucchiara, S. Inflammation Is The Main Determinant of Low Bone Mineral Density in Pediatric Inflammatory Bowel Disease. Inflamm. Bowel Dis. 2007, 13, 416-423. [CrossRef]

100. Lopes, L.H.C.; Sdepanian, V.L.; Szejnfeld, V.L.; De Morais, M.B.; Fagundes-Neto, U. Risk Factors for Low Bone Mineral Density in Children and Adolescents with Inflammatory Bowel Disease. Dig. Dis. Sci. 2008, 53, 2746-2753. [CrossRef]

101. Nobile, S.; Grand, R.J.; Pappa, H.M. Risk factors for low bone mineral density in pediatric inflammatory bowel disease: The positive role of physical activity. Eur. J. Gastroenterol. Hepatol. 2018, 30, 471-476. [CrossRef] [PubMed]

102. Sigurdsson, G.V.; Schmidt, S.; Mellström, D.; Ohlsson, C.; Kindblom, J.M.; Lorentzon, M.; Saalman, R. Bone Mass Development from Childhood into Young Adulthood in Patients with Childhood-onset Inflammatory Bowel Disease. Inflamm. Bowel Dis. 2017, 23, 2215-2226. [CrossRef]

103. Guz-Mark, A.; Rinawi, F.; Egotubov, O.; Shimon, I.; Shamir, R.; Assa, A. Pediatric-onset inflammatory bowel disease poses risk for low bone mineral density at early adulthood. Dig. Liver Dis. 2017, 49, 639-642. [CrossRef] [PubMed]

104. A Sentongo, T.; Semaeo, E.J.; Stettler, N.; A Piccoli, D.; A Stallings, V.; Zemel, B.S. Vitamin D status in children, adolescents, and young adults with Crohn disease. Am. J. Clin. Nutr. 2002, 76, 1077-1081. [CrossRef] [PubMed]

105. Levin, A.D.; Wadhera, V.; Leach, S.T.; Woodhead, H.J.; Lemberg, D.A.; Mendoza-Cruz, A.C.; Day, A.S. Vitamin D Deficiency in Children with Inflammatory Bowel Disease. Dig. Dis. Sci. 2011, 56, 830-836. [CrossRef]

106. Lee, R.; Maltz, R.M.; Crandall, W.V.; Plogsted, S.W.; Shaikhkhalil, A.K.; Bowden, S.A.; Mezoff, E.A. Single High-dose Vitamin D3 Supplementation in Pediatric Patients With Inflammatory Bowel Disease and Hypovitaminosis D. J. Pediatr. Gastroenterol. Nutr. 2020, 70, e77-e80. [CrossRef] [PubMed]

107. Alshahrani, F.; Aljohani, N. Vitamin D: Deficiency, Sufficiency and Toxicity. Nutrients 2013, 5, 3605-3616. [CrossRef]

108. Nielsen, O.H.; Rejnmark, L.; Moss, A.C. Role of Vitamin D in the Natural History of Inflammatory Bowel Disease. J. Crohn's Colitis 2018, 12, 742-752. [CrossRef] [PubMed]

109. Gubatan, J.; Chou, N.D.; Nielsen, O.H.; Moss, A.C. Systematic review with meta-analysis: Association of vitamin D status with clinical outcomes in adult patients with inflammatory bowel disease. Aliment. Pharmacol. Ther. 2019, 50, 1146-1158. [CrossRef]

110. El Amrousy, D.; El Ashry, H.; Hodeib, H.; Hassan, S. Vitamin D in Children With Inflammatory Bowel Disease. J. Clin. Gastroenterol. 2020. [CrossRef]

111. Guzman-Prado, Y.; Samson, O.; Segal, J.P.; Limdi, J.K.; Hayee, B. Vitamin D Therapy in Adults With Inflammatory Bowel Disease: A Systematic Review and Meta-Analysis. Inflamm. Bowel Dis. 2020, 26, 1819-1830. [CrossRef] [PubMed]

112. Armstrong, H.; Mander, I.; Zhang, Z.; Armstrong, D.; Wine, E. Not All Fibers Are Born Equal; Variable Response to Dietary Fiber Subtypes in IBD. Front. Pediatr. 2021, 8, 620189. [CrossRef] [PubMed]

113. Ríos-Covián, D.; Ruas-Madiedo, P.; Margolles, A.; Gueimonde, M.; Reyes-Gavilán, C.G.D.L.; Salazar, N. Intestinal Short Chain Fatty Acids and their Link with Diet and Human Health. Front. Microbiol. 2016, 7, 185. [CrossRef] [PubMed]

114. Sokol, H.; Lay, C.; Seksik, P.; Tannock, G.W. Analysis of bacterial bowel communities of IBD patients: What has it revealed? Inflamm. Bowel Dis. 2008, 14, 858-867. [CrossRef]

115. Pituch-Zdanowska, A.; Albrecht, P.; Banasiuk, M.; Banaszkiewicz, A. Dietary Fiber Intake in Children With Inflammatory Bowel Disease. J. Pediatr. Gastroenterol. Nutr. 2018, 66, 624-629. [CrossRef] [PubMed]

116. Costa, C.O.P.C.; Carrilho, F.J.; Nunes, V.S.; Sipahi, A.M.; Rodrigues, M. A snapshot of the nutritional status of Crohn's disease among adolescents in Brazil: A prospective cross-sectional study. BMC Gastroenterol. 2015, 15, 1-8. [CrossRef]

117. Levine, A.; Rhodes, J.M.; Lindsay, J.O.; Abreu, M.T.; Kamm, M.A.; Gibson, P.R.; Gasche, C.; Silverberg, M.S.; Mahadevan, U.; Boneh, R.S.; et al. Dietary Guidance From the International Organization for the Study of Inflammatory Bowel Diseases. Clin. Gastroenterol. Hepatol. 2020, 18, 1381-1392. [CrossRef] [PubMed]

118. Adamina, M.; Gerasimidis, K.; Sigall-Boneh, R.; Zmora, O.; Overstraeten, A.D.B.V.; Campmans-Kuijpers, M.; Ellul, P.; Katsanos, K.; Kotze, P.; Noor, N.; et al. DOP05 Perioperative Dietary Therapy in inflammatory bowel disease. J. Crohn's Colitis 2020, 14, S044. [CrossRef]

119. Lochs, H.; Allison, S.; Meier, R.; Pirlich, M.; Kondrup, J.; Schneider, S.; Berghe, G.V.D.; Pichard, C. Introductory to the ESPEN Guidelines on Enteral Nutrition: Terminology, Definitions and General Topics. Clin. Nutr. 2006, 25, 180-186. [CrossRef]

120. Narula, N.; Dhillon, A.; Zhang, D.; E Sherlock, M.; Tondeur, M.; Zachos, M. Enteral nutritional therapy for induction of remission in Crohn's disease. Cochrane Database Syst. Rev. 2018, 4, CD000542. [CrossRef]

121. Knight, C.; El-Matary, W.; Spray, C.; Sandhu, B.K. Long-term outcome of nutritional therapy in paediatric Crohn's disease. Clin. Nutr. 2005, 24, 775-779. [CrossRef]

122. Akobeng, A.K.; Thomas, A.G. Refeeding Syndrome Following Exclusive Enteral Nutritional Treatment in Crohn Disease. J. Pediatr. Gastroenterol. Nutr. 2010, 51, 364-366. [CrossRef] [PubMed]

123. Da Silva, J.S.V. ASPEN Consensus Recommendations for Refeeding Syndrome. Nutr. Clin. Pract. 2020, 35, 178-195. [CrossRef] [PubMed]

124. McCole, D.F. IBD Candidate Genes and Intestinal Barrier Regulation. Inflamm. Bowel Dis. 2014, 20, 1829-1849. [CrossRef] [PubMed] 
125. Kleessen, B.; Kroesen, A.J.; Buhr, H.J.; Blaut, M. Mucosal and Invading Bacteria in Patients with Inflammatory Bowel Disease Compared with Controls. Scand. J. Gastroenterol. 2002, 37, 1034-1041. [CrossRef] [PubMed]

126. Zaidi, D.; Bording-Jorgensen, M.; Huynh, H.Q.; Carroll, M.W.; Turcotte, J.-F.; Sergi, C.; Liu, J.; Wine, E. Increased Epithelial Gap Density in the Noninflamed Duodenum of Children With Inflammatory Bowel Diseases. J. Pediatr. Gastroenterol. Nutr. 2016, 63, 644-650. [CrossRef]

127. Fell, J.M.; Paintin, M.; Arnaud-Battandier, F.; Beattie, R.M.; Hollis, A.; Kitching, P.; Donnet-Hughes, A.; Macdonald, T.T.; Walker-Smith, J.A. Mucosal healing and a fall in mucosal pro-inflammatory cytokine mRNA induced by a specific oral polymeric diet in paediatric Crohn's disease. Aliment. Pharmacol. Ther. 2000, 14, 281-289. [CrossRef]

128. Yamamoto, T.; Nakahigashi, M.; Umegae, S.; Kitagawa, T.; Matsumoto, K. Impact of elemental diet on mucosal inflammation in patients with active Crohn's disease: Cytokine production and endoscopic and histological findings. Inflamm. Bowel Dis. 2005, 11, 580-588. [CrossRef] [PubMed]

129. De Jong, N.S.H.; Leach, S.T.; Day, A.S. Polymeric Formula Has Direct Anti-Inflammatory Effects on Enterocytes in an in VitroModel of Intestinal Inflammation. Dig. Dis. Sci. 2007, 52, 2029-2036. [CrossRef]

130. Nahidi, L.; Corley, S.M.; Wilkins, M.R.; Wei, J.; Alhagamhmad, M.; Day, A.S.; Lemberg, D.A.; Leach, S.T. The major pathway by which polymeric formula reduces inflammation in intestinal epithelial cells: A microarray-based analysis. Genes Nutr. 2015, 10, 29. [CrossRef]

131. Alhagamhmad, M.H. Enteral Nutrition in the Management of Crohn's Disease: Reviewing Mechanisms of Actions and Highlighting Potential Venues for Enhancing the Efficacy. Nutr. Clin. Pr. 2018, 33, 483-492. [CrossRef] [PubMed]

132. Schwerd, T.; Frivolt, K.; Clavel, T.; Lagkouvardos, I.; Katona, G.; Mayr, D.; Uhlig, H.H.; Haller, D.; Koletzko, S.; Bufler, P. Exclusive enteral nutrition in active pediatric Crohn disease: Effects on intestinal microbiota and immune regulation. J. Allergy Clin. Immunol. 2016, 138, 592-596. [CrossRef] [PubMed]

133. Wedrychowicz, A.; Kowalska-Duplaga, K.; Jedynak-Wasowicz, U.; Pieczarkowski, S.; Sladek, M.; Tomasik, P.; Fyderek, K. Serum Concentrations of VEGF and TGF- $\beta 1$ During Exclusive Enteral Nutrition in IBD. J. Pediatr. Gastroenterol. Nutr. 2011, 53, 150-155. [CrossRef]

134. Hahm, K.-B.; Im, Y.-H.; Parks, T.W.; Park, S.H.; Markowitz, S.D.; Jung, H.-Y.; Green, J.; Kim, S.J. Loss of transforming growth factor beta signalling in the intestine contributes to tissue injury in inflammatory bowel disease. Gut 2001, 49, 190-198. [CrossRef] [PubMed]

135. Triantafillidis, J.K.; Tzouvala, M.; Triantafyllidi, E. Enteral Nutrition Supplemented with Transforming Growth Factor- $\beta$, Colostrum, Probiotics, and Other Nutritional Compounds in the Treatment of Patients with Inflammatory Bowel Disease. Nutrients 2020, 12, 1048. [CrossRef]

136. I Keenan, J.; Hooper, E.M.; Tyrer, P.C.; Day, A.S. Influences of enteral nutrition upon CEACAM6 expression by intestinal epithelial cells. Innate Immun. 2013, 20, 848-856. [CrossRef]

137. Budd, G.R.; Aitchison, A.; Day, A.S.; I Keenan, J. The effect of polymeric formula on enterocyte differentiation. Innate Immun. 2017, 23, 240-248. [CrossRef] [PubMed]

138. Nahidi, L.; Day, A.S.; Lemberg, D.A.; Leach, S.T. Differential effects of nutritional and non-nutritional therapies on intestinal barrier function in an in vitro model. J. Gastroenterol. 2011, 47, 107-117. [CrossRef]

139. Hansen, R.; Russell, R.K.; Reiff, C.; Louis, P.; McIntosh, F.; Berry, S.H.; Mukhopadhya, I.; Bisset, M.W.; Barclay, A.R.; Bishop, J.; et al. Microbiota of De-Novo Pediatric IBD: Increased Faecalibacterium Prausnitzii and Reduced Bacterial Diversity in Crohn's But Not in Ulcerative Colitis. Am. J. Gastroenterol. 2012, 107, 1913-1922. [CrossRef] [PubMed]

140. Hedin, C.R.; E McCarthy, N.; Louis, P.; Farquharson, F.M.; McCartney, S.; Taylor, K.; Prescott, N.J.; Murrells, T.; Stagg, A.J.; Whelan, K.; et al. Altered intestinal microbiota and blood T cell phenotype are shared by patients with Crohn's disease and their unaffected siblings. Gut 2014, 63, 1578-1586. [CrossRef]

141. Treem, W.R.; Ahsan, N.; Shoup, M.; Hyams, J.S. Fecal Short-Chain Fatty Acids in Children with Inflammatory Bowel Disease. J. Pediatr. Gastroenterol. Nutr. 1994, 18, 159-164. [CrossRef]

142. Bjerrum, J.T.; Wang, Y.; Hao, F.; Coskun, M.; Ludwig, C.; Günther, U.; Nielsen, O.H. Metabonomics of human fecal extracts characterize ulcerative colitis, Crohn's disease and healthy individuals. Metabolomics 2015, 11, 122-133. [CrossRef] [PubMed]

143. Duboc, H.; Rajca, S.; Rainteau, D.; Benarous, D.; Maubert, M.-A.; Quervain, E.; Thomas, G.; Barbu, V.; Humbert, L.; Despras, G.; et al. Connecting dysbiosis, bile-acid dysmetabolism and gut inflammation in inflammatory bowel diseases. Gut 2013, 62, 531-539. [CrossRef] [PubMed]

144. Diederen, K.; Li, J.V.; Donachie, G.E.; De Meij, T.G.; De Waart, D.R.; Hakvoort, T.B.M.; Kindermann, A.; Wagner, J.; Auyeung, V.; Velde, A.A.T.; et al. Exclusive enteral nutrition mediates gut microbial and metabolic changes that are associated with remission in children with Crohn's disease. Sci. Rep. 2020, 10, 1-17. [CrossRef] [PubMed]

145. Lionetti, P.; Callegari, M.L.; Ferrari, S.; Cavicchi, M.C.; Pozzi, E.; De Martino, M.; Morelli, L. Enteral Nutrition and Microflora in Pediatric Crohn's Disease. J. Parenter. Enter. Nutr. 2005, 29, S173-S178. [CrossRef] [PubMed]

146. Gerasimidis, K.; Bertz, M.; Hanske, L.; Junick, J.; Biskou, O.; Aguilera, M.; Garrick, V.; Russell, R.K.; Blaut, M.; McGrogan, P.; et al. Decline in Presumptively Protective Gut Bacterial Species and Metabolites Are Paradoxically Associated with Disease Improvement in Pediatric Crohn's Disease During Enteral Nutrition. Inflamm. Bowel Dis. 2014, 20, 861-871. [CrossRef] 
147. Logan, M.; Gkikas, K.; Svolos, V.; Nichols, B.; Milling, S.; Gaya, D.R.; Seenan, J.P.; Macdonald, J.; Hansen, R.; Ijaz, U.Z.; et al. Analysis of 61 exclusive enteral nutrition formulas used in the management of active Crohn's disease-new insights into dietary disease triggers. Aliment. Pharmacol. Ther. 2020, 51, 935-947. [CrossRef] [PubMed]

148. Quince, C.; Ijaz, U.Z.; Loman, N.; A Eren, M.; Saulnier, D.; Russell, J.; Haig, S.J.; Calus, S.T.; Quick, J.; Barclay, A.; et al. Extensive Modulation of the Fecal Metagenome in Children With Crohn's Disease During Exclusive Enteral Nutrition. Am. J. Gastroenterol. 2015, 110, 1718-1729. [CrossRef]

149. Voitk, A.J. Experience With Elemental Diet in the Treatment of Inflammatory Bowel Disease: Is This Primary Therapy? Arch. Surg. 1973, 107, 329. [CrossRef] [PubMed]

150. Morin, C.L.; Roulet, M.; Roy, C.C.; Weber, A. Continuous elemental enteral alimentation in children with Crohn's disease and growth failure. Gastroenterology 1980, 79, 1205-1210. [CrossRef]

151. Sanderson, I.R.; Udeen, S.; Davies, P.S.; O Savage, M.; A Walker-Smith, J. Remission induced by an elemental diet in small bowel Crohn's disease. Arch. Dis. Child. 1987, 62, 123-127. [CrossRef] [PubMed]

152. Swaminath, A.; Feathers, A.; Ananthakrishnan, A.; Falzon, L.; Ferry, S.L. Systematic review with meta-analysis: Enteral nutrition therapy for the induction of remission in paediatric Crohn's disease. Aliment. Pharmacol. Ther. 2017, 46, 645-656. [CrossRef] [PubMed]

153. Levine, A. Comparison of Outcomes Parameters for Induction of Remission in New Onset Pediatric Crohn's Disease: Evaluation of the Porto IBD Group "Growth Relapse and Outcomes with Therapy" (GROWTH CD) Study. Inflamm. Bowel Dis. 2014, 20, 278-285. [CrossRef] [PubMed]

154. Lee, D.; Baldassano, R.N.; Otley, A.R.; Albenberg, L.; Griffiths, A.M.; Compher, C.; Chen, E.Z.; Lindsey, A.; Gilroy, E.; Nessel, L.; et al. Comparative Effectiveness of Nutritional and Biological Therapy in North American Children with Active Crohn's Disease. Inflamm. Bowel Dis. 2015, 21, 1786-1793. [CrossRef] [PubMed]

155. Shah, S.C.; Colombel, J.-F.; E Sands, B.; Narula, N. Systematic review with meta-analysis: Mucosal healing is associated with improved long-term outcomes in Crohn's disease. Aliment. Pharmacol. Ther. 2016, 43, 317-333. [CrossRef]

156. Grover, Z.; Muir, R.; Lewindon, P. Exclusive enteral nutrition induces early clinical, mucosal and transmural remission in paediatric Crohn's disease. J. Gastroenterol. 2014, 49, 638-645. [CrossRef] [PubMed]

157. Borrelli, O.; Cordischi, L.; Cirulli, M.; Paganelli, M.; Labalestra, V.; Uccini, S.; Russo, P.M.; Cucchiara, S. Polymeric Diet Alone Versus Corticosteroids in the Treatment of Active Pediatric Crohn's Disease: A Randomized Controlled Open-Label Trial. Clin. Gastroenterol. Hepatol. 2006, 4, 744-753. [CrossRef]

158. Grover, Z.; Burgess, C.; Muir, R.; Reilly, C.; Lewindon, P.J. Early Mucosal Healing with Exclusive Enteral Nutrition is Associated with Improved Outcomes in Newly Diagnosed Children with Luminal Crohn's disease. J. Crohn's Colitis 2016, 10, 1159-1164. [CrossRef]

159. Buchanan, E.; Gaunt, W.W.; Cardigan, T.; Garrick, V.; McGrogan, P.; Russell, R.K. The use of exclusive enteral nutrition for induction of remission in children with Crohn's disease demonstrates that disease phenotype does not influence clinical remission. Aliment. Pharmacol. Ther. 2009, 30, 501-507. [CrossRef] [PubMed]

160. Afzal, N.A.; Davies, S.; Paintin, M.; Arnaud-Battandier, F.; Walker-Smith, J.A.; Murch, S.; Heuschkel, R.; Fell, J. Colonic Crohn's Disease in Children Does Not Respond Well to Treatment with Enteral Nutrition If the Ileum Is Not Involved. Dig. Dis. Sci. 2005, 50, 1471-1475. [CrossRef]

161. Day, A.S.; E Whitten, K.; A Lemberg, D.; Clarkson, C.; Vitug-Sales, M.; Jackson, R.; Bohane, T.D. Exclusive enteral feeding as primary therapy for Crohn's disease in Australian children and adolescents: A feasible and effective approach. J. Gastroenterol. Hepatol. 2006, 21, 1609-1614. [CrossRef] [PubMed]

162. Belli, D.; Seidman, E.; Bouthillier, L.; Weber, A.; Roy, C.; Pletincx, M.; Beaulieu, M.; Morin, C. Chronic intermittent elemental diet improves growth failure in children with Crohn's disease. Gastroenterology 1988, 94, 603-610. [CrossRef]

163. Polk, D.B.; Hattner, J.A.T.; Kerner, J.A. Improved Growth and Disease Activity After Intermittent Administration of a Defined Formula Diet in Children With Crohn's Disease. J. Parenter. Enter. Nutr. 1992, 16, 499-504. [CrossRef]

164. Patel, K.V.; Darakhshan, A.A.; Griffin, N.; Williams, A.B.; Sanderson, J.D.; Irving, P.M. Patient optimization for surgery relating to Crohn's disease. Nat. Rev. Gastroenterol. Hepatol. 2016, 13, 707-719. [CrossRef]

165. Heerasing, N.; Thompson, B.; Hendy, P.; Heap, G.A.; Walker, G.; Bethune, R.; Mansfield, S.; Calvert, C.; Kennedy, N.A.; Ahmad, T.; et al. Exclusive enteral nutrition provides an effective bridge to safer interval elective surgery for adults with Crohn's disease. Aliment. Pharmacol. Ther. 2017, 45, 660-669. [CrossRef]

166. Ge, X.; Tang, S.; Yang, X.; Liu, W.; Ye, L.; Yu, W.; Xu, H.; Cao, Q.; Zhou, W.; Cai, X. The role of exclusive enteral nutrition in the preoperative optimization of laparoscopic surgery for patients with Crohn's disease: A cohort study. Int. J. Surg. 2019, 65, 39-44. [CrossRef] [PubMed]

167. Grass, F.; Pache, B.; Martin, D.; Hahnloser, D.; Demartines, N.; Hübner, M. Preoperative Nutritional Conditioning of Crohn's Patients-Systematic Review of Current Evidence and Practice. Nutrients 2017, 9, 562. [CrossRef]

168. Jacobson, S. Early postoperative complications in patients with Crohn's disease given and not given preoperative total parenteral nutrition. Scand. J. Gastroenterol. 2012, 47, 170-177. [CrossRef] [PubMed]

169. Wang, H.; Zuo, L.; Zhao, J.; Dong, J.; Li, Y.; Gu, L.; Gong, J.; Liu, Q.; Zhu, W. Impact of Preoperative Exclusive Enteral Nutrition on Postoperative Complications and Recurrence After Bowel Resection in Patients with Active Crohn's Disease. World J. Surg. 2016, 40, 1993-2000. [CrossRef] 
170. Li, Y.; Zuo, L.; Zhu, W.; Gong, J.; Zhang, W.; Gu, L.; Guo, Z.; Cao, L.; Li, N.; Li, J. Role of Exclusive Enteral Nutrition in the Preoperative Optimization of Patients With Crohn's Disease Following Immunosuppressive Therapy. Medicine 2015, 94 , e478. [CrossRef]

171. Li, G.; Ren, J.; Wang, G.; Hu, D.; Gu, G.; Liu, S.; Ren, H.; Wu, X.; Li, J. Preoperative exclusive enteral nutrition reduces the postoperative septic complications of fistulizing Crohn's disease. Eur. J. Clin. Nutr. 2014, 68, 441-446. [CrossRef]

172. Harris, R.E.; Duncan, H.; Buchanan, E.; Cardigan, T.; Garrick, V.; Curtis, L.; Gervais, L.; Barclay, A.; Haddock, G.; Hansen, R.; et al. Prehabilitation: The Impact of Preoperative Exclusive Enteral Nutrition on Paediatric Patients With Crohn Disease. J. Pediatr. Gastroenterol. Nutr. 2020, 70, 503-507. [CrossRef] [PubMed]

173. Whitten, K.E.; Leach, S.T.; Bohane, T.D.; Woodhead, H.J.; Day, A.S. Effect of exclusive enteral nutrition on bone turnover in children with Crohn's disease. J. Gastroenterol. 2009, 45, 399-405. [CrossRef]

174. Strisciuglio, C.; Scarpato, E.; Cenni, S.; Serra, M.; Giugliano, F.; Mainolfi, C.; Dolce, P.; Martinelli, M.; Staiano, A.; Miele, E. Improvement of body composition and bone mineral density after enteral nutrition in pediatric Crohn disease. Dig. Liver Dis. 2020, 52, 630-636. [CrossRef]

175. Lev-Tzion, R.; Ben-Moshe, T.; Abitbol, G.; Ledder, O.; Peleg, S.; Millman, P.; Shaoul, R.; Kori, M.; Assa, A.; Cohen, S.; et al. The Effect of Nutritional Therapy on Bone Mineral Density and Bone Metabolism in Pediatric Crohn's Disease. J. Pediatr. Gastroenterol. Nutr. 2021. [CrossRef] [PubMed]

176. Johnson, T.; Macdonald, S.; Hill, S.M.; Thomas, A.; Murphy, M.S. Treatment of active Crohn's disease in children using partial enteral nutrition with liquid formula: A randomised controlled trial. Gut 2006, 55, 356-361. [CrossRef]

177. Gupta, K.; Noble, A.; Kachelries, K.E.; Albenberg, L.; Kelsen, J.R.; Grossman, A.B.; Baldassano, R.N. A Novel Enteral Nutrition Protocol for the Treatment of Pediatric Crohn's Disease. Inflamm. Bowel Dis. 2013, 19, 1374-1378. [CrossRef]

178. Wilschanski, M.; Sherman, P.; Pencharz, P.; Davis, L.; Corey, M.; Griffiths, A. Supplementary enteral nutrition maintains remission in paediatric Crohn's disease. Gut 1996, 38, 543-548. [CrossRef]

179. Duncan, H.; Buchanan, E.; Cardigan, T.; Garrick, V.; Curtis, L.; McGrogan, P.; Barclay, A.; Russell, R.K. A retrospective study showing maintenance treatment options for paediatric CD in the first year following diagnosis after induction of remission with EEN: Supplemental enteral nutrition is better than nothing! BMC Gastroenterol. 2014, 14, 50. [CrossRef]

180. Schulman, J.M.; Pritzker, L.; Shaoul, R. Maintenance of Remission with Partial Enteral Nutrition Therapy in Pediatric Crohn's Disease: A Retrospective Study. Can. J. Gastroenterol. Hepatol. 2017, 1-7. [CrossRef] [PubMed]

181. Gavin, J.; Ashton, J.J.; Heather, N.; Marino, L.V.; Beattie, R.M. Nutritional support in paediatric Crohn's disease: Outcome at 12 months. Acta Paediatr. 2017, 107, 156-162. [CrossRef]

182. Logan, M.; Clark, C.M.; Ijaz, U.Z.; Gervais, L.; Duncan, H.; Garrick, V.; Curtis, L.; Buchanan, E.; Cardigan, T.; Armstrong, L.; et al. The reduction of faecal calprotectin during exclusive enteral nutrition is lost rapidly after food re-introduction. Aliment. Pharmacol. Ther. 2019, 50, 664-674. [CrossRef]

183. Takagi, S.; Utsunomiya, K.; Kuriyama, S.; Yokoyama, H.; Takahashi, S.; Iwabuchi, M.; Kinouchi, Y.; Hiwatashi, N.; Funayama, Y.; Sasaki, I.; et al. Effectiveness of an 'half elemental diet' as maintenance therapy for Crohn's disease: A randomized-controlled trial. Aliment. Pharmacol. Ther. 2006, 24, 1333-1340. [CrossRef] [PubMed]

184. Hanai, H.; Iida, T.; Takeuchi, K.; Arai, H.; Arai, O.; Abe, J.; Tanaka, T.; Maruyama, Y.; Ikeya, K.; Sugimoto, K.; et al. Nutritional therapy versus 6-mercaptopurine as maintenance therapy in patients with Crohn's disease. Dig. Liver Dis. 2012, 44, 649-654. [CrossRef]

185. Hirai, F.; Takeda, T.; Takada, Y.; Kishi, M.; Beppu, T.; Takatsu, N.; Miyaoka, M.; Hisabe, T.; Yao, K.; Ueki, T. Efficacy of enteral nutrition in patients with Crohn's disease on maintenance anti-TNF-alpha antibody therapy: A meta-analysis. J. Gastroenterol. 2020, 55, 133-141. [CrossRef]

186. Gkikas, K.; Gerasimidis, K.; Milling, S.; Ijaz, U.Z.; Hansen, R.; Russell, R.K. Dietary Strategies for Maintenance of Clinical Remission in Inflammatory Bowel Diseases: Are We There Yet? Nutrients 2020, 12, 2018. [CrossRef]

187. Jones, V.A. Comparison of total parenteral nutrition and elemental diet in induction of remission of Crohn's disease. Dig. Dis. Sci. 1987, 32, S100-S107. [CrossRef] [PubMed]

188. Woolner, J.T.; Parker, T.J.; Kirby, G.A.; Hunter, J.O. The development and evaluation of a diet for maintaining remission in Crohn's disease. J. Hum. Nutr. Diet. 1998, 11, 1-11. [CrossRef]

189. Faiman, A.; Mutalib, M.; Moylan, A.; Morgan, N.; Crespi, D.; Furman, M.; Kader, A. Standard versus rapid food reintroduction after exclusive enteral nutritional therapy in paediatric Crohn's disease. Eur. J. Gastroenterol. Hepatol. 2014, 26, 276-281. [CrossRef] [PubMed]

190. Levine, A.; Wine, E. Effects of enteral nutrition on Crohn's disease: Clues to the impact of diet on disease pathogenesis. Inflamm. Bowel. Dis. 2013, 19, 1322-1329. [CrossRef]

191. Nickerson, K.P.; Chanin, R.; McDonald, C. Deregulation of intestinal anti-microbial defense by the dietary additive, maltodextrin Gut Microbes 2015, 6, 78-83. [CrossRef] [PubMed]

192. Chassaing, B.; Koren, O.; Goodrich, J.K.; Poole, A.C.; Srinivasan, S.; Ley, R.E.; Gewirtz, A.T. Dietary emulsifiers impact the mouse gut microbiota promoting colitis and metabolic syndrome. Nat. Cell Biol. 2015, 519, 92-96. [CrossRef]

193. Nickerson, K.P.; Homer, C.R.; Kessler, S.P.; Dixon, L.J.; Kabi, A.; Gordon, I.O.; Johnson, E.E.; De La Motte, C.A.; McDonald, C. The Dietary Polysaccharide Maltodextrin Promotes Salmonella Survival and Mucosal Colonization in Mice. PLoS ONE 2014, 9, e101789. [CrossRef] 
194. Herrador-López, M.; Martín-Masot, R.; Navas-López, V.M. EEN Yesterday and Today CDED Today and Tomorrow. Nutrients 2020, 12, 3793. [CrossRef]

195. Sigall-Boneh, R.; Pfeffer-Gik, T.; Segal, I.; Zangen, T.; Boaz, M.; Levine, A. Partial enteral nutrition with a Crohn's disease exclusion diet is effective for induction of remission in children and young adults with Crohn's disease. Inflamm. Bowel Dis. 2014, 20, 1353-1360. [CrossRef] [PubMed]

196. Boneh, R.S.; Van Limbergen, J.; Wine, E.; Assa, A.; Shaoul, R.; Milman, P.; Cohen, S.; Kori, M.; Peleg, S.; On, A.; et al. Dietary Therapies Induce Rapid Response and Remission in Pediatric Patients With Active Crohn's Disease. Clin. Gastroenterol. Hepatol. 2021, 19, 752-759. [CrossRef] [PubMed]

197. Debruyn, J.C.; Jacobson, K.; El-Matary, W.; Carroll, M.; Wine, E.; Wrobel, I.; Van Woudenberg, M.; Huynh, H.Q. Long-term Outcomes of Infliximab Use for Pediatric Crohn Disease: A Canadian Multicenter Clinical Practice Experience. J. Pediatr. Gastroenterol. Nutr. 2018, 66, 268-273. [CrossRef]

198. Faubion, W.A.; Dubinsky, M.; Ruemmele, F.M.; Escher, J.; Rosh, J.; Hyams, J.S.; Lazar, A. Long-term Efficacy and Safety of Adalimumab in Pediatric Patients with Crohn's Disease. Inflamm. Bowel Dis. 2017, 23, 453-460. [CrossRef] [PubMed]

199. Boneh, R.S.; Shabat, C.S.; Yanai, H.; Chermesh, I.; Ben Avraham, S.; Boaz, M.; Levine, A. Dietary Therapy With the Crohn's Disease Exclusion Diet is a Successful Strategy for Induction of Remission in Children and Adults Failing Biological Therapy. J. Crohn's Colitis 2017, 11, 1205-1212. [CrossRef]

200. Turner, D.; Griffiths, A.M.; Wilson, D.; Mould, D.R.; Baldassano, R.N.; Russell, R.K.; Dubinsky, M.; Heyman, M.B.; De Ridder, L.; Hyams, J.; et al. Designing clinical trials in paediatric inflammatory bowel diseases: A PIBDnet commentary. Gut 2020, 69, 32-41. [CrossRef] [PubMed]

201. Seyed Tabib, N.S.; Madgwick, M.; Sudhakar, P.; Verstockt, B.; Korcsmaros, T.; Vermeire, S. Big data in IBD: Big progress for clinical practice. Gut 2020, 69, 1520-1532. [CrossRef] [PubMed] 